\title{
MicroRNA: a prognostic biomarker and a possible druggable target for circumventing multidrug resistance in cancer chemotherapy
}

\author{
Kenneth KW To
}

\begin{abstract}
Multidrug resistance (MDR) is a major obstacle to successful cancer treatment. It is often associated with an increased efflux of a variety of structurally unrelated anticancer drugs by ATP-binding cassette (ABC) transporters including P-gp, ABCG2 and MRP1. MicroRNAs (miRNAs) are small non-coding RNAs that govern posttranscriptional regulation of target genes by interacting with specific sequences in their $3^{\prime}$ untranslated region ( $3^{\prime} \cup T R$ ), thereby promoting mRNA degradation or suppressing translation. Accumulating evidence suggests that alterations in miRNAs contribute to resistance to anticancer drugs. While miRNAs are well-known to be dysregulated in cancer, recent literature revealed that miRNA levels in biological samples may be correlated with chemotherapy response. This review summarized the coordinated network by which miRNA regulated MDR transporters. The usefulness of miRNAs as prognostic biomarkers for predicting chemotherapeutic outcome is discussed. MiRNAs may also represent druggable targets for circumvention of MDR.
\end{abstract}

Keywords: ATP-binding cassette transporters, microRNA, Multidrug resistance, Non-coding RNAs, Prognostic biomarkers, 3' untranslated region

\section{Introduction}

Resistance to anticancer drugs remains a major unresolved obstacle to successful chemotherapy. It has been estimated that most cancer deaths, if not all, are caused by chemotherapy failure because tumors quickly develop resistance after exposure to drugs [1]. In order to develop novel strategies to combat cancer drug resistance and to improve patient survival, a thorough understanding of its mechanisms is therefore badly needed. The causes of cancer drug resistance are multifactorial, including decreased accumulation/increased disposition of anticancer drugs, mutation of drug targets, enhanced cell repair and altered cell death pathways. However, the most common and extensively studied mechanism is the overexpression of the energy-dependent ATP-binding cassette $(A B C)$ drug efflux transporters such as P-glycoprotein (MDR-1/P-gp/ABCB1), multidrug

Correspondence: kennethto@cuhk.edu.hk

School of Pharmacy, Room 801 N, Lo Kwee-Seong Integrated Biomedical Sciences Building, Faculty of Medicine, The Chinese University of Hong Kong, Area 39, Shatin, New Territories, Hong Kong SAR, China resistance related protein (MRP-1/ABCC1), and breast cancer resistance protein (BCRP/MXR/ABCP/ABCG2) [2]. It is associated with an increased efflux of cytotoxic drugs, causing multidrug resistance (MDR) because cytotoxic drugs from different chemical structures are affected simultaneously.

MicroRNAs (miRNAs) are short endogenous noncoding RNAs that repress gene expression in a variety of eukaryotic organisms. Gene regulation by miRNAs is mediated by the formation of imperfect hybrids with the 3 'untranslated region (3'UTR) sequences of the target mRNAs, leading to mRNA degradation and/or translational inhibition [3]. They play important roles in several cellular processes, such as proliferation, differentiation, apoptosis, and development, by simultaneously controlling the expression level of hundreds of genes. MiRNAs are predicted to regulate the expression of up to one third of human protein-coding genes [4-6].

Numerous recent studies have shown that miRNA expression profiles differ between normal tissues and cancerous cells derived from the same organ, and also 
between cancer types [7]. MiRNAs can act as oncogenes or tumor suppressors, contributing to different pathways in tumorigenesis [8,9]. They may be used for diagnostic and prognostic purposes and they also constitute novel targets for cancer treatment $[10,11]$. Recently, the evidence for the roles of miRNAs in determining drug sensitivity/resistance has been emerging. This review summarized the current understanding about the role of miRNAs in mediating cancer drug resistance. More emphasis is placed on miRNA-related regulation of the MDR transporters, though other mechanisms causing drug resistance not related to transporters will also be discussed. The possible application of miRNA-transporters regulatory network for predicting chemotherapeutic response will be highlighted. Novel strategies aiming to target miRNA-related pathways for the circumvention of multidrug resistance will also be elaborated.

\section{Review}

\section{Aberrant expression of miRNAs and cancer drug} resistance

Evidence pointing to the role of miRNAs in determining drug sensitivity and MDR is emerging. MiRNA expression is largely dysregulated in drug-resistant cancer cells $[12,13]$. In a recent study on a doxorubicin-resistant breast cancer cell line MCF-7/DOX, a profound dysregulation of the miRNA profile and altered expression of two important miRNA processing enzymes Dicer and Argonaute 2 was reported [14]. The remarkable correlation between specific miRNA expression and the corresponding changes in protein levels of their specific targets having well-documented role in cancer drug resistance, may thus implies a mechanistic link between miRNAome dysregulation and the MDR phenotype. Moreover, miRNA expression patterns in the NCI-60 drug screen cell lines are significantly correlated to the sensitivity patterns of the cancer cells for a variety of anticancer drugs [15]. Furthermore, numerous miRNAs have been found to regulate drug resistance genes such as ABCG2 [16-18], BCL2 [19], DHFR [20], MDR1 [14] and PTEN [21]. Importantly, modulation of miRNA expression or function can alter sensitivity of cancer cells to anticancer drugs. This could be achieved by inhibiting the function of up-regulated miRNAs or restoring the expression of down-regulated miRNAs. Together, miRNAs may represent key players in both intrinsic and acquired MDR in cancer cells [22].

The cause of cancer drug resistance is multifactorial. The role of miRNAs in mediating cancer drug resistance is separately discussed below according to whether they are regulating to (I) MDR transporters-mediated (Table 1); or (II) non-MDR transporters-mediated mechanisms (Table 2). The list is by no means exhaustive. We aim to illustrate the representative ones with potentially wider implications.

\section{Regulation of ABC transporters-mediated MDR by miRNAs}

Direct regulation by miRNAs

$A B C G 2$ (also known as $B C R P / M X R / A B C P$ )

ABCG2 is the first MDR transporter reported to be regulated by miRNA-mediated mechanism. It is one of the major $\mathrm{ABC}$ transporters contributing to the MDR phenotype. Overexpression of the $A B C G 2$ gene is frequently observed in cancer cell lines selected with chemotherapeutic drugs $[2,45]$. To date, most studies examining the regulation of ABCG2 have focused on transcription. Gene amplification, chromosome translocation, and the use of alternative $5^{\prime}$ promoters due to differential expression of splice variants at the $5^{\prime}$-untranslated region (5'UTR) of ABCG2 mRNA have been reported to play important roles in the increased expression of ABCG2 [46,47]. In contrast, the understanding about posttranscriptional regulation of ABCG2 has just started to evolve.

To date, a few miRNAs (miR-520 h [36,37], -519c [16,17], -328 [18], -181a [38], \& -487a [39]) have been identified by different research groups independently to regulate ABCG2 expression by interacting directly with ABCG2 3'UTR and to determine the sensitivity of cancer cells to chemotherapeutic drugs (Table 1). Consistent with the hypothesis that aberrant miRNA expression can cause cancer drug resistance, low miR-328 expression was found to correlate with the overexpression of ABCG2 in resistant MCF-7/MX100 breast cancer cells [18]. In a human retinoblastoma cell line model, it has been further demonstrated that low expressions of all three miRNAs (miR-328, -519c, \& -520 h) correlate very well with high ABCG2 expression, with concomitant expression of other stem cell markers including CD133 and ALDH1A1 [35]. On the other hand, miR-520 h has been reported to promote differentiation of hematopoietic stem cells by inhibiting ABCG2 expression [36]. ABCG2 has been suggested to be a survival factor for stem or cancer stem cells (CSCs) [48]. Thus these findings collectively support an important role played by miRNAs in maintaining high ABCG2 level in CSCs, leading to drug resistance. It will be interesting to verify if the same phenomenon is also observed in tumor samples from patients not responding to cancer chemotherapy.

Drug-resistant cancer cells escape miR-519c-mediated ABCG2 repression by shortening of ABCG2 mRNA 3' UTR An additional layer of complexity in miR-519cmediated regulation of ABCG2 has been proposed, which is associated with alternative cleavage and polyadenylation of the 3'UTR of ABCG2 mRNA, to facilitate the drug resistance phenotype [17]. ABCG2 mRNA was found to be more stable in drug-selected and ABCG2-overexpressing resistant cell lines than in their parental counterparts [16,17]. Given that the expression 
Table 1 miRNAs reported to regulate MDR transporters to mediate chemoresistance

\begin{tabular}{|c|c|c|c|c|c|c|c|}
\hline $\begin{array}{l}\text { Transporter } \\
\text { targets }\end{array}$ & $\begin{array}{l}\text { MicroRNA } \\
\text { dysregulation }\end{array}$ & Direct binding site(s) on target gene? & $\begin{array}{l}\text { Prediction by miRNA } \\
\text { database(s) }\end{array}$ & Identification method & Cancer type & $\begin{array}{l}\text { Study in } \\
\text { patient } \\
\text { samples? }\end{array}$ & Reference \\
\hline \multirow[t]{14}{*}{$\mathrm{ABCB1}$} & miR-27a个 & $\begin{array}{l}\text { Indirect regulation-targets HIPK2 (a transcriptional } \\
\text { corepressor that inhibits HIF-1aactivity), thereby } \\
\text { indirectly activating MDR-1/P-gp }\end{array}$ & $\begin{array}{l}\text { TargetScan suggests } \\
\text { that HIPK2 is a possible } \\
\text { target for miR-27a }\end{array}$ & $\begin{array}{l}\text { Serendipitous testing of miR-27a } \\
\text { in the development of drug } \\
\text { resistance in ovarian cancer } \\
\text { cell lines }\end{array}$ & Ovarian & No & [23] \\
\hline & \multirow[t]{3}{*}{ 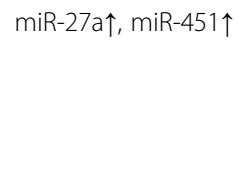 } & Likely indirect regulation & \multirow[t]{3}{*}{-} & \multirow[t]{3}{*}{ miRNA microarray profiling } & \multirow[t]{3}{*}{ Ovarian } & \multirow[t]{3}{*}{ No } & \multirow[t]{3}{*}{ [24] } \\
\hline & & (i.e. not via $A B C B 13^{\prime} U T R$ ) & & & & & \\
\hline & & $\begin{array}{l}\text { miR-27a \& miR-451 mimics elevate ABCB1 } \\
\text { mRNA }\end{array}$ & & & & & \\
\hline & 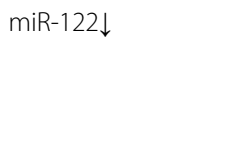 & $\begin{array}{l}\text { NO attempt to verify binding of miR-122 on } \\
\text { MDR-1 } 3^{\prime} U T R\end{array}$ & NOT performed & $\begin{array}{l}\text { Serendipitous testing of } \\
\text { downregulation of MDR } \\
\text { related genes (MDR-1, } \\
\text { MRP \& GST- } \pi \text { ) by miR-122 }\end{array}$ & $\begin{array}{l}\text { Hepatocellular } \\
\text { carcinoma }\end{array}$ & No & [25] \\
\hline & \multirow[t]{3}{*}{$\operatorname{miR}-296 \uparrow$} & Likely indirect regulation & \multirow[t]{3}{*}{-} & \multirow[t]{3}{*}{ miRNA microarray profiling } & \multirow{3}{*}{$\begin{array}{l}\text { Esophageal } \\
\text { squamous cell } \\
\text { carcinoma }\end{array}$} & \multirow[t]{3}{*}{ Yes } & \multirow[t]{3}{*}{ [26] } \\
\hline & & (i.e. not via $A B C B 13^{\prime} U T R$ ) & & & & & \\
\hline & & $\begin{array}{l}\text { - antagomir of miR-296 decrease ABCB1 } \\
\text { promoter activity }\end{array}$ & & & & & \\
\hline & 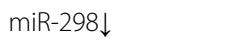 & \multirow{2}{*}{$\begin{array}{l}\text { Confirmed by luciferase reporter assay / MDR-1 } \\
\text { 3'UTR miRNA site deletion / miRNA mimic / } \\
\text { miRNA inhibitor }\end{array}$} & \multirow[t]{6}{*}{ miRanda } & \multirow[t]{6}{*}{ miRNA microarray } & \multirow[t]{2}{*}{ Breast cancer } & \multirow[t]{2}{*}{ No } & \multirow[t]{2}{*}{ [27] } \\
\hline & 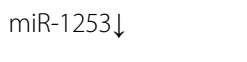 & & & & & & \\
\hline & \multirow[t]{4}{*}{ let-7 g $\downarrow$} & Indirect regulation & & & \multirow[t]{4}{*}{ Ovarian } & \multirow[t]{4}{*}{ Yes } & \multirow[t]{4}{*}{ [28] } \\
\hline & & - targets IMP-1 (a RNA-binding protein) & & & & & \\
\hline & & - IMP-1 is known to stabilize MDR1 mRNA & & & & & \\
\hline & & $\begin{array}{l}\text { - loss of let-7 g commonly observed in various } \\
\text { cancers could therefore allow overexpression of } \\
\text { IMP-1 and stability of MDR-1/P-gp to mediate } \\
\text { drug resistance }\end{array}$ & & & & & \\
\hline \multirow[t]{2}{*}{$A B C C 1$} & 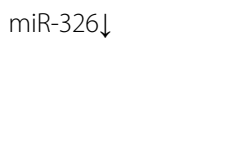 & $\begin{array}{l}\text { Confirmed by luciferase reporter assay / ABCC1 } \\
3^{\prime} U T R \text { miRNA site deletion / gene expression } \\
\text { analysis after transfection with miR-326 } \\
\text { mimic }\end{array}$ & TargetScan & miRNA microarray profiling & $\begin{array}{l}\text { Breast cell line + } \\
\text { early/advanced } \\
\text { breast cancer } \\
\text { tissue }\end{array}$ & Yes & [29] \\
\hline & 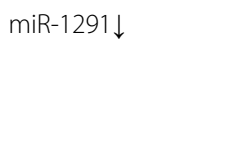 & $\begin{array}{l}\text { Confirmed by luciferase reporter/miRNA } \\
\text { mimic/miRNA inhibitor }\end{array}$ & $\begin{array}{l}\text { RNAhybrid, TargetScan, } \\
\text { miRanda, PITA }\end{array}$ & $\begin{array}{l}\text { Serendipitous study of the role of } \\
\text { SNORA34 to generate miR-1291, } \\
\text { which subsequently controls } \\
\text { chemosensitivity }\end{array}$ & Pancreatic & No & [30] \\
\hline$A B C C 2$ & 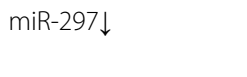 & $\begin{array}{l}\text { Luciferase reporter/miRNA mimic/miRNA } \\
\text { inhibitor }\end{array}$ & TargetScan & miRNA microarray profiling & Colorectal & Yes & [31] \\
\hline \multirow{2}{*}{$\begin{array}{l}A B C C 3 \& \\
A B C C 6\end{array}$} & \multirow[t]{2}{*}{ miR-9* $\downarrow$} & Indirect regulation - & \multirow{2}{*}{$\begin{array}{l}\text { PicTar, TargetScan, } \\
\text { miRBase, miRanda }\end{array}$} & \multirow{2}{*}{$\begin{array}{l}\text { Serendipitous study of the role of } \\
\text { ID4 in chemoresistance of induced } \\
\text { glioma stem cells }\end{array}$} & \multirow[t]{2}{*}{ Glioma } & \multirow[t]{2}{*}{ Yes } & \multirow[t]{2}{*}{ [32] } \\
\hline & & - miR-9* is a SOX2-targeting miRNA & & & & & \\
\hline
\end{tabular}


Table 1 miRNAs reported to regulate MDR transporters to mediate chemoresistance (Continued)

\begin{tabular}{|c|c|c|c|c|c|c|c|}
\hline & & $\begin{array}{l}\text { - novel ID4-miR-9*-SOX2-ABCC3/ABCC6 } \\
\text { regulatory pathway }\end{array}$ & & & & & \\
\hline & & $\begin{array}{l}\text { - ID4 was found to confer chemoresistance } \\
\text { to glioma stem cells by inducing the } \\
\text { expression of two SOX2-mediated ABC } \\
\text { transporters (ABCC3 \& ABCC6) through } \\
\text { suppression of miR-9** }\end{array}$ & & & & & \\
\hline \multirow[t]{9}{*}{$\mathrm{ABCG} 2$} & 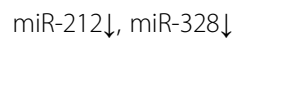 & $\begin{array}{l}\text { Effect of miR-212 \& miR-328 on ABCG2 } \\
\text { expression was evaluated by gene expression } \\
\text { analysis and luciferase reporter gene assay }\end{array}$ & - & $\begin{array}{l}\text { miRNA microarray profiling in } \\
\text { imatinib-selected K562 cells }\end{array}$ & $\begin{array}{l}\text { Leukemia (short- } \\
\text { term /long-term } \\
\text { imatinib treatmet) }\end{array}$ & No & [33] \\
\hline & miR-328 $\downarrow$ & $\begin{array}{l}\text { Confirmed by luciferase reporter assay / } \\
\text { ABCG2 3'UTR miRNA site deletion / miRNA } \\
\text { mimic / miRNA antagomir }\end{array}$ & PITA; TargetScan & Bioinformatic analysis & Breast & No & [18] \\
\hline & miR-328 $\downarrow$ & $\begin{array}{l}\text { Confirmed by luciferase reporter assay / } \\
\text { gene expression analysis after transfection } \\
\text { with miRNA mimic or inhibitor }\end{array}$ & - & $\begin{array}{l}\text { miRNA microarray analysis on } \\
S P^{\#} \text { vs non-SP\# cells }\end{array}$ & $\begin{array}{l}\text { Colorectal cell lines } \\
\text { + primary biopsies }\end{array}$ & Yes & [34] \\
\hline & $\begin{array}{l}\text { miR-328 } \downarrow \text {, miR-519c } \downarrow \text {, } \\
\text { miR-520 h } \downarrow\end{array}$ & $\begin{array}{l}\text { Confirmed by luciferase reporter assay with } \\
\text { site-directed gene mutagenesis / gene } \\
\text { expression analysis after transfection with } \\
\text { miRNA mimics }\end{array}$ & $\begin{array}{l}\text { TargetScan, PITA, } \\
\text { MicroCosm Targets, RNA22 }\end{array}$ & Bioinformatic analysis & $\begin{array}{l}\text { Breast, Stem-like } \\
\text { cells from human } \\
\text { retinoblastoma }\end{array}$ & No & {$[35]$} \\
\hline & $\begin{array}{l}\text { miR-519c (shortening } \\
\text { of ABCG2 } 3^{\prime} U T R \text { escape } \\
\text { miR-519c repression) }\end{array}$ & 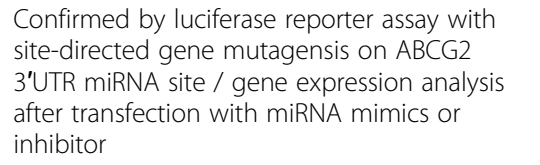 & $\begin{array}{l}\text { miRBase TARGETS, } \\
\text { RNAHybrid, UTRScan } \\
\text { program }\end{array}$ & Bioinformatic analysis & Colon & No & {$[16,17]$} \\
\hline & miR-520 h $\downarrow$ & $\begin{array}{l}\text { Confirmed by luciferase reporter assay }+/ \text { - } \\
\text { miRNA mimic \& inhibitor }\end{array}$ & $\begin{array}{l}\text { PicTar, miRanda, } \\
\text { TargetScan }\end{array}$ & $\begin{array}{l}\text { miRNA microarray profiling of } \\
\text { CD34+ hematopoietic cells }\end{array}$ & Leukemia & No & {$[36]$} \\
\hline & miR-520 h $\downarrow$ & $\begin{array}{l}\text { Confirmed by gene expression analysis after } \\
\text { miRNA mimic transfection }\end{array}$ & $\begin{array}{l}\text { miRanda, TargetScan, } \\
\text { TarBase }\end{array}$ & Bioinformatic analysis & Pancreatic & No & {$[37]$} \\
\hline & miR-181a $\downarrow$ & $\begin{array}{l}\text { Confirmed by luciferase reporter assay and } \\
\text { gene expression analysis +/- miRNA mimic } \\
\text { \& inhibitor }\end{array}$ & RNAhybrid & $\begin{array}{l}\text { miRNA microarray analysis to } \\
\text { compare sensitive and resistant } \\
\text { cells }\end{array}$ & Breast & No & {$[38]$} \\
\hline & miR-487a $\downarrow$ & $\begin{array}{l}\text { Confirmed by luciferase reporter assay and } \\
\text { gene expression analysis }+/ \text { - miRNA mimic } \\
\& \text { inhibitor Confirmed by luciferase reporter } \\
\text { assay and gene expression analysis +/- miRNA } \\
\text { mimic \& inhibitor }\end{array}$ & $\begin{array}{l}\text { TargetScan, PITA, } \\
\text { RNAhybrid }\end{array}$ & Bioinformatic analysis & Breast & No & [39] \\
\hline
\end{tabular}

${ } \mathrm{SP}=$ side population; Non-SP = non-side population. 
Table 2 miRNAs reported to regulate other mediators of drug resistance

\begin{tabular}{|c|c|c|c|c|c|c|c|c|}
\hline $\begin{array}{l}\text { Target } \\
\text { gene }\end{array}$ & $\begin{array}{l}\text { Biological effect } \\
\text { of target gene }\end{array}$ & MicroRNA & $\begin{array}{l}\text { Validation of miRNA } \\
\text { binding site }\end{array}$ & $\begin{array}{l}\text { Prediction by miRNA } \\
\text { database(s) }\end{array}$ & Identification method & $\begin{array}{l}\text { Cancer type/Significance/Specific } \\
\text { type of drug resistance }\end{array}$ & $\begin{array}{l}\text { Study in } \\
\text { patient } \\
\text { samples? }\end{array}$ & Reference \\
\hline$B A X$ & Pro-apoptotic & $\operatorname{miR}-296 \uparrow$ & $\begin{array}{l}\text { Luciferase reporter } \\
\text { assay + miRNA } \\
\text { antagomir }\end{array}$ & - & miRNA microarray profiling & Esophageal squamous cell carcinoma & Yes & [26] \\
\hline$B C L 2$ & Anti-apoptotic & 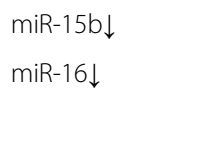 & 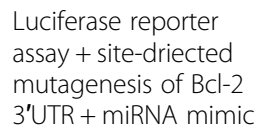 & miRBase \& TargetScan & miRNA microarray profiling & Gastric & No & [19] \\
\hline$B C L 2$ & Anti-apoptotic & 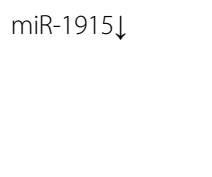 & $\begin{array}{l}\text { Luciferase reporter } \\
\text { assay + site-directed } \\
\text { mutagenesis of Bcl-2 } \\
\text { 3'UTR + miRNA mimics }_{\text {\& inhibitors }}\end{array}$ & $\begin{array}{l}\text { miRDB; TargetScan } \\
(4 \text { possible miRNA } \\
\text { binding sites within } \\
\text { Bcl-2 } 3^{\prime} \text { UTR) }\end{array}$ & miRNA microarray profiling & Colorectal & No & {$[40]$} \\
\hline \multirow[t]{2}{*}{$\begin{array}{l}\text { BCL2 \& } \\
\text { SIRT1 }\end{array}$} & \multirow[t]{2}{*}{ Anti-apoptotic } & \multirow[t]{2}{*}{ miR-34a $\downarrow$} & $\begin{array}{l}\text { Direct miRNA effect } \\
\text { (on Bcl-2 \& SIRT1 } \\
\text { mRNA): Luciferase } \\
\text { reporter +/- miRNA } \\
\text { mimic }\end{array}$ & \multirow[t]{2}{*}{ TargetScan } & \multirow[t]{2}{*}{$\begin{array}{l}\text { Mechanistic investigation of } \\
\text { miR-34a/Bcl-2 and miR-34a/ } \\
\text { SIRT1 pathways in taxane- } \\
\text { based chemotherapy }\end{array}$} & \multirow[t]{2}{*}{ Prostate / Paclitaxel resistance } & \multirow[t]{2}{*}{ No } & \multirow[t]{2}{*}{ [41] } \\
\hline & & & $\begin{array}{l}\text { Indirect miRNA effect } \\
\text { (through HuR): Gene } \\
\text { expression analysis +/- } \\
\text { miRNA mimic }\end{array}$ & & & & & \\
\hline$B M I-1$ & $\begin{array}{l}\mathrm{PcG}^{\mathrm{a}} \text { protein - } \\
\text { transcriptional } \\
\text { repressor }\end{array}$ & miR-200c $\downarrow$ & $\begin{array}{l}\text { Gene expression } \\
\text { analysis after infection } \\
\text { with miR-200c vector }\end{array}$ & - & miRNA microarray analysis & $\begin{array}{l}\text { Melanoma /miR-200c is commonly found } \\
\text { to be downregulated in malignant melanoma } \\
\text { that possess self-renewal cancer stem-cell like } \\
\text { property and are more invasive. The prominent } \\
\text { miR-200c downregulation is accompanied by } \\
\text { Bmi-1 overexpression, which was found to } \\
\text { cause loss of E-cadherin (thereby EMT) and } \\
\text { overexpression of MDR transporters (including } \\
\text { ABCG2, ABCG5 and MDR). }\end{array}$ & Yes & [42] \\
\hline \multirow[t]{2}{*}{$\mathrm{CDH} 1$} & \multirow[t]{2}{*}{$\mathrm{EMT}^{\mathrm{b}}$ transition } & $m R-200 c \downarrow$ & \multirow{2}{*}{$\begin{array}{l}\text { Indirect regulation: } \\
\text { The two miRNAs } \\
\text { repress ZEB1 \& ZEB2, } \\
\text { thereby leading to loss } \\
\text { of E-cadherin and a } \\
\text { EMT phenotype }\end{array}$} & \multirow[t]{2}{*}{-} & \multirow{2}{*}{$\begin{array}{l}\text { Mechanistic investigation of } \\
\text { the role of miRNAs in EMT- } \\
\text { linked docetaxel resistance in } \\
\text { prostate cancer }\end{array}$} & \multirow{2}{*}{$\begin{array}{l}\text { Prostate/Docetaxel resistance/Docetaxel } \\
\text { treatment triggers EMT to inhibit apoptosis } \\
\text { through the proposed miR-200c/205/ZEB1/ } \\
\text { ZEB2/E-cadherin pathway }\end{array}$} & \multirow[t]{2}{*}{ No } & \multirow[t]{2}{*}{ [43] } \\
\hline & & 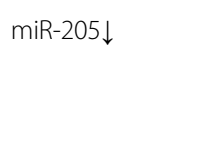 & & & & & & \\
\hline DHFR & $\begin{array}{l}\text { Folate } \\
\text { metabolism }\end{array}$ & $\begin{array}{l}\text { miR-24 (DHFR } \\
\text { SNP } 829 C>T \\
\text { makes DHFR } \\
\text { mRNA indifferent } \\
\text { to miR-24) }\end{array}$ & $\begin{array}{l}\text { Gene expression } \\
\text { analysis + Site-directed } \\
\text { mutagenesis + miRNA } \\
\text { mimics \& inhibitors }\end{array}$ & MiRanda \& miRBase & $\begin{array}{l}\text { A } 829 \text { C > T SNP identified in } \\
\text { DHFR gene in Japanese } \\
\text { population was found to be } \\
\text { associated with increased } \\
\text { DHFR message }\end{array}$ & Fibrosarcoma/methotrexate resistance & No & [20] \\
\hline HIPK2 & $\begin{array}{l}\text { Tumor } \\
\text { suppressor }\end{array}$ & $\operatorname{miR}-27 a \uparrow$ & $\begin{array}{l}\text { NO attempt to verify } \\
\text { binding of miR-27a on } \\
\text { HIPK2 3'UTR }\end{array}$ & TargetScan & $\begin{array}{l}\text { Identified during the study of } \\
\text { indirect effect of miR-27a on } \\
\text { MDR-1 expression }\end{array}$ & Ovarian & No & [23] \\
\hline
\end{tabular}


Table 2 miRNAs reported to regulate other mediators of drug resistance (Continued)

\begin{tabular}{|c|c|c|c|c|c|c|c|c|}
\hline PTEN & $\begin{array}{l}\text { Tumor } \\
\text { suppressor }\end{array}$ & $\operatorname{miR}-214 \uparrow$ & 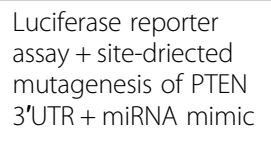 & - & miRNA microarray profiling & Ovarian/cisplatin resistance & Yes & [21] \\
\hline TUBB3 & $\begin{array}{l}\text { Structural protein } \\
\text { ( } \beta \text {-tubulin) }\end{array}$ & miR-200c $\downarrow$ & $\begin{array}{l}\text { Gene expression } \\
\text { analysis }+/ \text { - miRNA } \\
\text { mimic }\end{array}$ & - & miRNA microarray profiling & $\begin{array}{l}\text { Resistance to microtubule -binding } \\
\text { chemotherapeutic drugs }\end{array}$ & No & [44] \\
\hline
\end{tabular}

a PCG = polycomb group protein (transcriptional repressor).

EMT = epithelial-to-mesenchymal transition. 
level of miR-519c in the parental and resistant cells does not differ too much in the cell line model studied, the increase in mRNA stability was subsequently tied to a missing miR-519c binding site in the truncated 3'UTR of ABCG2 mRNA in drug resistant cells [17]. MiR-519c cannot bind to ABCG2 mRNA in the resistant cells because of the shorter 3'UTR, and thus miRNA-mediated mRNA degradation and/or protein translation block are relieved, contributing to ABCG2 overexpression (Figure 1).

In eukaryotes, polyadenylation is an important process that produces mature mRNA for translation. A poly(A) tail is added to $3^{\prime}$ end of mRNA at the end of transcription, which protects the mRNA molecule from enzymatic degradation in the cytoplasm, aids in transcription termination, export of the mRNA from nucleus, and translation [49]. Importantly, alternative polyadenylation can occur when several polyA signals lie in the last exon of a protein-coding gene, generating mRNA isoforms with different 3'UTR length. While the phenomenon of alternative cleavage and polyadenylation has been known for decades, it has only been fully appreciated recently [50]. The majority of human genes contain at least two polyA sites [51], and alternative cleavage and polyadenylation has been shown to be fairly common in multiple organisms [50]. In general, proliferative cells, such as induced pluripotent stem cells and cancer cells, show a global shortening of 3'UTR as compared with their less proliferative counterparts [52-55]. As gene regulation mechanisms mediated at the 3'UTRs are mostly repressive, it is generally assumed that a truncated 3'UTR will result in higher mRNA and/or protein levels [50]. It has been reported that 3'UTR shortening of oncogene
mRNAs in cancer cells leads to increased protein abundance $[54,56]$. Intriguingly, the truncation of the ABCG2 3'UTR has also been reported in an undifferentiated human embryonic stem (HuES) cell line where its high ABCG2 expression was associated with the short 3'UTR variant forms [57]. In contrast, another differentiated HuES cell line with lower ABCG2 levels possesses a longer 3'UTR variant [57]. Sandberg et al. also found that rapidly proliferating cells express ABCG2 mRNA with shorter 3'UTRs, presumably to escape miRNA regulation [52].

\section{$A B C B 1$ (MDR-1/P-gp)}

ABCB1 (MDR-1/P-gp) is the most extensively studied MDR transporter, which was discovered more than 30 years ago [58]. Overexpression of MDR-1/P-gp confers cancer cells resistance to a broad range of structurally and functionally diverse chemotherapeutic drugs [59]. It was proposed to express in more than $50 \%$ of all drug-resistant human tumors. Not long after the identification of the miRNAs regulating ABCG2, a few miRNAs directly repressing $A B C B 1$ through binding to its 3'UTR (miR-27a, -451, -296, -298, -338, -1253) have been reported (Table 1; [14,26,27]). Downregulation of these miRNAs in resistant cancer cells leads to drug resistance.

\section{ABCC1 (MRP-1)}

Multidrug resistance-associated protein (ABCC1/MRP-1) transports a wide range of different drug classes and is also known to play a critical role in the development of MDR in cancer cells. Among the major MDR transporters, the

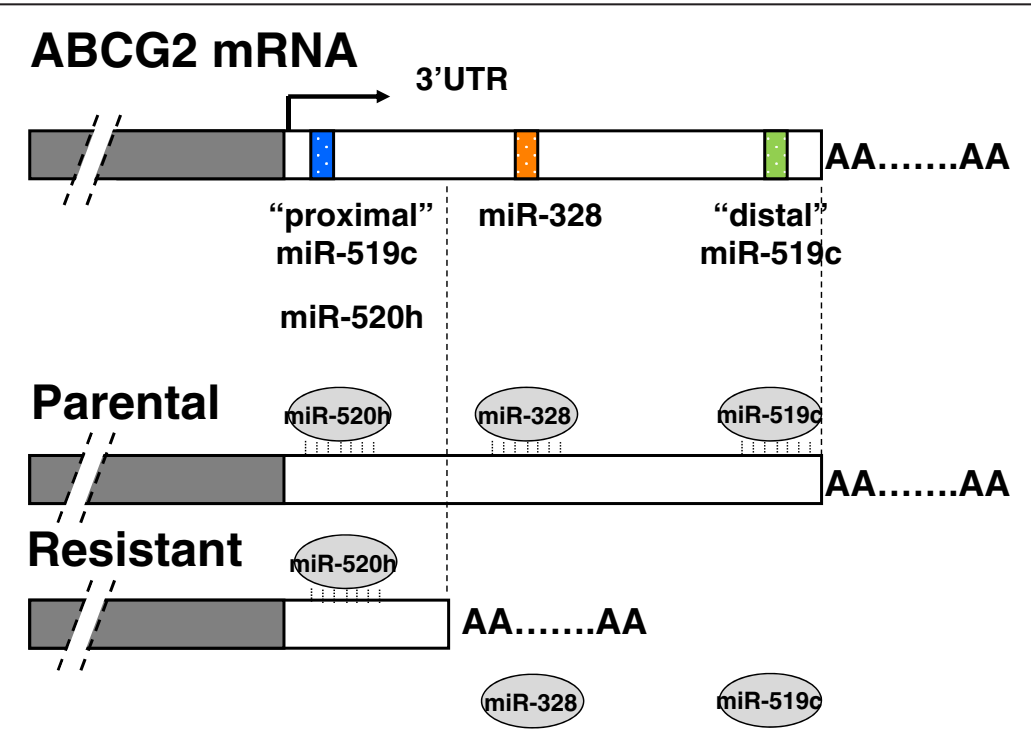

Figure 1 A proposed model for ABCG2 regulation by miR-519c. ABCG2 mRNA adopts predominantly a long form of 3'UTR in parental S1 cells but only the shorter forms in drug-resistant S1M1-80 cancer cell line $[16,17]$. MiR-519c (and miR-328) can only bind to the long ABCG2 3'UTR in parental cells, thus allowing ABCG2 in resistant cells to escape from their repression and thereby acquiring a higher expression. 
regulation of MRP-1 by miRNAs is the least studied. To date, only miR-326 [29] and miR-1291 [30] were reported to modulate MRP-1 expression directly via interacting with its 3'UTR. In VP-16-selected MRP-1-overexpressing MCF-7 resistant cells, miR-326 was found to be downregulated and lead to MRP-1 overexpression. MiR-1291 has just been recently reported to mediate doxorubicin resistance in pancreatic cancer cells by targeting $\mathrm{ABCC}$ [30]. It was derived from a small nucleolar RNA (snoRNA: miR-1291/SNORA34), a new class of non-coding regulatory RNAs that is known to control the posttranscriptional modification of ribosomal RNAs [30]. The tissue or cell type specific processing of SNORA34 to miR-1291, and thus the overexpression of miR-1291, in pancreatic cancer may allow the development of tumor targeting therapy to combat MDR by selectively intervening the miR-1291 pathway.

\section{ABCC2 (MRP-2)}

MDR-associated protein 2 (MRP-2) is a unique $A B C$ transporter that can mediate platinum (Pt) drug resistance [60]. Pt-based anticancer drugs, including cisplatin and oxaliplatin, are the mainstay of treatment for most solid tumors. $\mathrm{ABCC} 2$ can recognize $\mathrm{GSH}$-conjugated form of Pt drugs and effectively pump them out of the cells to confer resistance. To date, only miR-297 has been reported to be down-regulated in a oxaliplatinresistant colon cancer cell model (HCT116/L-OHP) to cause $\mathrm{ABCC} 2$ overexpression and Pt drug resistance [31]. A complementary binding site for miR-297 was identified on ABCC2 3'UTR to mediate the specific gene repression.

\section{Indirect regulation by miRNAs MDR-1/P-gp}

Besides the various miRNAs discussed above that can directly modulate MDR-1/P-gp expression by interacting with complementary sequences at its 3 'UTR, indirect regulation of the MDR transporter has also been reported. Let-7 $\mathrm{g}$ was reported to modulate acquired resistance of ovarian cancer to taxanes via IMP-1-mediated stabilization of MDR-1 [28]. IMP-1 is an RNA binding protein that stabilizes the mRNA of a number of target genes, including MDR-1 [61]. IMP-1 was known to be a validated target for let-7 $\mathrm{g}$ [62]. It follows that the loss of let-7 $\mathrm{g}$ commonly observed in various cancers [28] could allow the overexpression of IMP-1 and thereby stabilization of MDR-1/P-gp to mediate anticancer drug resistance (Figure 2a; [28]). Moreover, a novel miR-27a/HIPK2/MDR1/P-gp pathway has been proposed that lead to paclitaxel resistance in ovarian cancer cells [23]. Homeodomain-interacting protein kinase-2 (HIPK2) was reported to inhibit HIF$1 \alpha$, thereby suppressing $M D R 1$ gene transcription and sensitize cancer cells to doxorubicin-induced apoptosis
[63]. Therefore, increased expression of miR-27a in resistant cells leads to downregulation of HIPK2, which indirectly allows HIF- $1 \alpha$-mediated stimulation of MDR-1/ P-gp and chemoresistance (Figure 2b; [23]).

Another noteworthy indirect mechanism for miRNAmediated upregulation of MDR-1/P-gp involved the epigenetic alteration (i.e. hypomethylation) of the $M D R-1$ promoter in resistant MCF-7/DOX cells (Figure 2c; [64]). The loss of cytosine methylation in the MDR-1 promoter, which was shown to lead to P-gp overexpression and the resistance phenotype, was proposed to be mediated by the increased expression of miR-22, miR29a, miR-132, and miR194. These miRNAs were known to target DNA methyltransferases $3 \mathrm{~A}$ and $3 \mathrm{~B}$ and methyl CpG binding protein 2, which mediate $M D R-1$ promoter methylation [64-66]. Although the definitive proof for this hypothesis is still lacking, it has far-reaching implication in the etiology of MDR. A number of other key mediators of MDR (including ABCG2, BCL-2, PTEN, etc) are known to be repressed by DNA methylation, therefore aberrant increased expression of the aforementioned miRNAs in cancer cells may lead to derepression of these mediators to cause MDR.

\section{$A B C C 3 / A B C C 6$}

Unlike most $A B C$ transporters that are highly expressed in various anatomic regions of the normal brain, $\mathrm{ABCC} 3$ and $\mathrm{ABCC} 6$ are not detectable in normal brain tissues [67]. Surprisingly, the specific role played by these two $\mathrm{ABC}$ transporters in the anticancer drug resistance of glioma stem cells has been recently reported [32]. A novel regulatory pathway Inhibitor of differentiation 4 (ID4)-miR-9*-SOX2-ABCC3/ABCC6 was proposed, which induces the stemness potential of glioma stem cells and chemoresistance (Figure 3). Of note, ABCC3 and ABCC6 are not direct targets for miR-9*. However, both of these $\mathrm{ABC}$ transporters are transcriptionally regulated by SOX2, which is elevated in glioma stem cells by ID4-mediated suppression of miR-9*.

\section{Regulation of MDR via non-transporter-mediated pathways by miRNAs}

Alternations of several oncogenes (e.g. Bcl2, Ras, Src) and tumor suppressor genes (e.g. p53, RB, and p16) are closely associated with chemoresistance. However, the involvement of miRNA in these processes has just begun to be unraveled. A list of the most representative miRNAs regulating these non-transporter-mediated MDR pathways is summarized in Table 2. The list is by no means exhaustive but it aims to highlight a few examples according to the biological effect of the miRNA target gene (i.e. anti-apoptotic, drug metabolism, tumor suppressor, epithelial-to-mesenchymal transition (EMT)). 
(a)

$$
\begin{aligned}
& \text { let-7g-1MP-1 } \\
& \begin{array}{c}
\text { dysregulation: } \\
\qquad \text { level }
\end{array}
\end{aligned}
$$

(b)

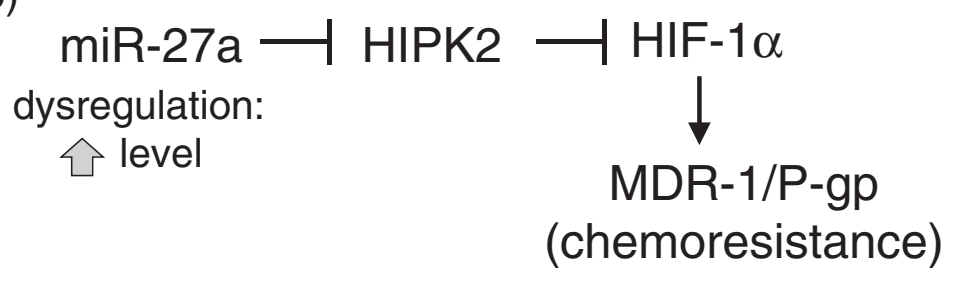

(c)

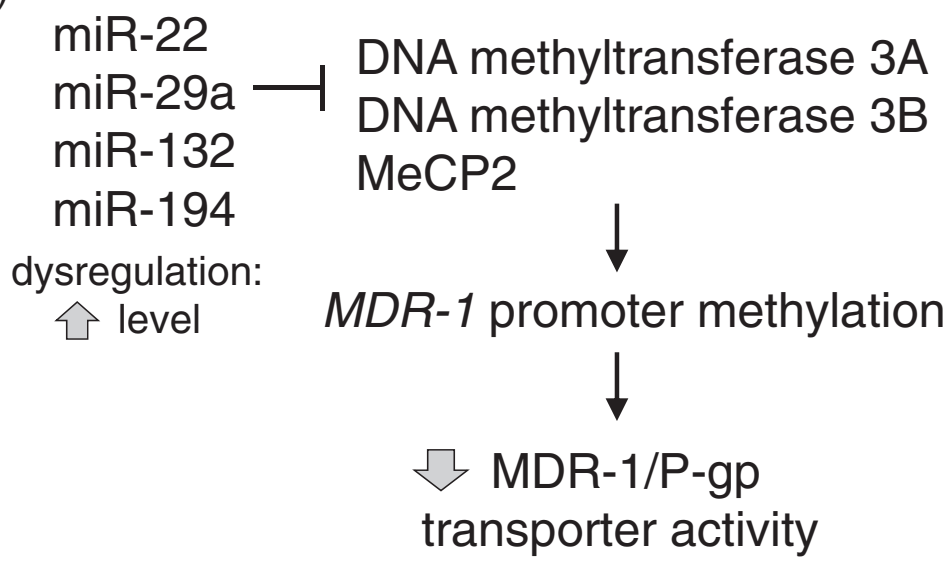

Figure 2 Indirect regulatory mechanisms of MDR-1/P-gp by miRNAs. (a) let-7 g downregulation is commonly observed in various cancers. It is known to target the RNA binding protein, IMP-1, which stabilizes MDR-1 mRNA. Therefore, let-7 $\mathrm{g}$ loss in resistant cells allows overexpression of IMP-1 and stability of MDR-1/P-gp to mediate drug resistance [28]. (b) Homeodomain-interacting protein kinase-2 (HIPK2) is a known target of miR-27a. HIPK2 has also been reported to inhibit HIF-1a. Increased expression of miR-27a in resistant cells leads to downregulation of HIPK2, which indirectly allows HIF-1a-mediated stimulation of MDR-1/P-gp and chemoresistance [23]. (c) A hypothetical miRNAs-DNA methylation machinery-MDR-1 promoter methylation pathway. Increased expression of these miRNAs in resistant cells represses various DNA methylation mediators, thereby facilitating MDR-1 promoter demethylation and increasing P-gp efflux activity to mediate chemoresistance.

(a) Anti-apoptotic

Most anticancer drugs work by induction of apoptosis. Alterations to susceptibility to apoptosis may lead to resistance to conventional cancer chemotherapy. BCL2 (encoding the protein known as apoptosis regulator $\mathrm{Bcl}-2$ ) is the most important prosurvival or anti-apoptotic factor often overexpressed in cancer and it is closely associated with chemotherapy resistance in various cancers. A number of miRNAs (including miR-15b, -16, -34a, -296, -1915) have been shown to modulate MDR by targeting BCL2 $[19,26,40,41]$. MiR-34a is of particular interest, where both direct and indirect regulatory pathways have

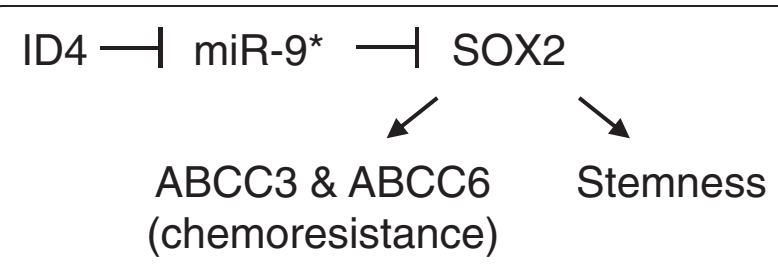

Figure $3 \mathrm{miR}-9$ * is involved in an indirect regulatory mechanism of $\mathrm{ABCC} 3$ \& $\mathrm{ABCC} 6$ to induce chemoresistance and stemness in glioma stem cells. 
been described (Figure 4a; [41]). MiR-34a can inhibit proliferation of paclitaxel-resistant PC3PR cells by directly suppressing expression of proteins involved in cell-cycle regulation such as CDK6 and cyclin D1. On the other hand, miR-34a has also been shown to enhance apoptosis by indirectly reducing expression of SIRT1 and $\mathrm{Bcl} 2$ via modulating HuR.

(b) Drug metabolism

Dihydrofolate reductase (DHFR) is a key enzyme in cellular folate metabolism, which is the drug target of a widely used anticancer drug methotrexate. A naturally occurring SNP of DHFR $(829 \mathrm{C}>\mathrm{T})$ has been identified near the miR-24 binding site within the $3^{\prime}$ UTR of DHFR [20]. It interferes with miR-24 repression, thus resulting in DHFR overexpression and methotrexate resistance.

(c) Tumor suppressor

A growing list of miRNAs has been identified to regulate PTEN, an important tumor suppressor, by binding to its $3^{\prime} \mathrm{UTR}[21,68,69]$. For example, miR-
214 was shown to interact with PTEN 3'UTR and inhibit PTEN translation, thereby leading to activation of the Akt pathway and cisplatin resistance [21]. The significance of this finding is that, once the miRNA-mediated regulation pathway is understood, apart from artificially altering the miRNA expression, the resistance phenotype can also be overridden by modulation of the upstream or downstream events (such as using either small-molecule Akt inhibitor or etopic expression of PTEN cDNA lacking $3^{\prime}$ UTR) [21].

(d) Epithelial-to-mesenchymal transition (EMT) EMT is a cellular process that describes the change of an epithelial to a motile mesenchymal phenotype. Upon EMT, primary epithelial cancer cells acquire increased invasive and migratory abilities, eventually leading to metastases. Cancer cells selected for docetaxel resistance was found to exhibit EMTtriggered E-cadherin loss and reduced apoptosis [43]. Detailed mechanistic study revealed that these

\section{(a)}

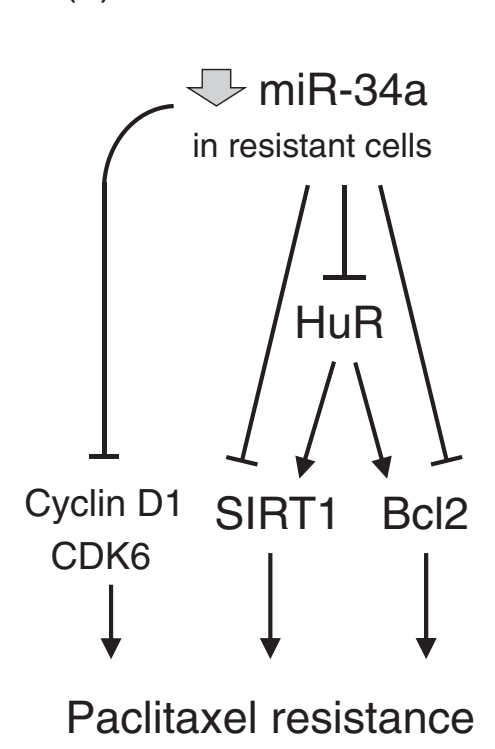

(b)

\section{Docetaxel selection for resistant cells}

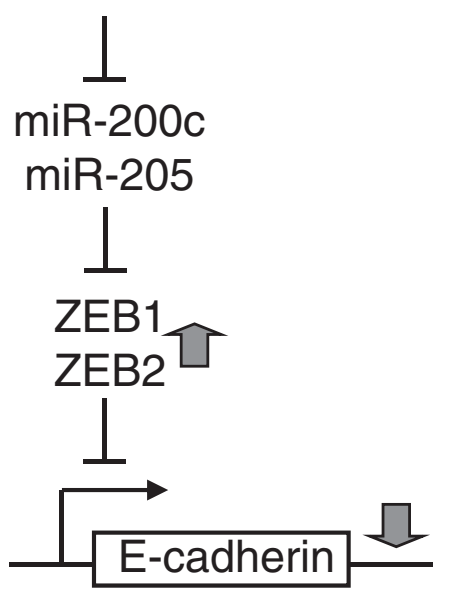

\section{EMT phenotype \\ Resistance to apoptosis}

Figure 4 miR-34a mediates paclitaxel resistance via both direct and indirect mechanisms. (a) Schematic representation of direct and indirect mechanisms underlying miR-34a-mediated paclitaxel resistance. Direct pathway: miR-34a inhibit proliferation of paclitaxel-resistant PC3PR cells by directly suppressing the cell cycle regulators cyclin D1 and CDK6. Indirect pathway: miR-34a can enhance apoptosis by indirectly reducing expression of the anti-apoptotic gens (SIRT1 \& BCL2) via modulating HuR [41]. (b) Indirect mechanism of miR-200c/-205-mediated EMT and resistance to apoptosis. Key signals that lead to EMT trigger expression of a variety of transcriptional repressors, including ZEB1, ZEB2/SIP1, Snail, and Twist. These repressors are the intracellular mediators of EMT by binding to E-box elements of genes, such as CDH1, that encode for the adhesion protein E-cadherin. After binding, they recruit histone deacetylases and other corepressors to facilitate transcriptional repression of E-cadherin. Reduced cellular E-cadherin expression subsequently will lead to loss of cell-cell adhesion and a series of other events, eventually leading to an invasive mesenchymal and drug resistance phenotype [43]. 
resistant cells have significantly reduced expression of miR-200c \& -205. MiR-200c \& -205 repress the transcriptional repressors, ZEB1/ZEB2, therefore reduced levels of these miRNAs allow more repression by ZEB1/ZEB2 and thereby downregulation of E-cadherin and EMT (Figure 4b; [43]). Another recent report by Liu et al. shown that miR-200c downregulation is frequently observed in metastatic melanoma, which is accompanied by overexpression of its target Bmi-1 (a Polycomb group protein class of transcriptional repressor) [42]. Upregulation of Bmi-1 was further shown to increase a number of MDR transporter genes (ABCG2, MDR1 and ABCG5) and to mediate loss of E-cadherin, collectively leading to a more resistant, malignant, and invasive EMT-like phenotype [42].

\section{Genetic polymorphism in miRNA binding sites and anti-cancer drug resistance}

Regulation by miRNAs depends on the binding to seed sequences in the 3'UTR of their target mRNAs, which subsequently leads to degradation of mRNAs and/or translation blockade. Therefore, both sequence complementarity and thermodynamics of the binding determine the likelihood of interaction between miRNAs and their targets. It follows that sequence variations such as singlenucleotide polymorphisms (SNPs) in the miRNA target site (more specifically in the seed region) could affect the miRNA-mRNA interaction and subsequently expression of the miRNA targets. To this end, a recent bioinformatics study of the entire human genome revealed a relatively high frequency of miRNA target site SNPs that disrupt target sites or create new ones [70].

The most popular SNP occurring at miRNA target site, related to anticancer drug resistance, is probably the one identified by Mishra et al. on a miR-24 binding sequence that changed cell response to methotrexate [20]. The SNP $(829 \mathrm{C} \rightarrow \mathrm{T})$ near the miR-24 binding site in the 3'UTR of human dihydrofolate reductase (DHFR) was found to interfere with miR-24-mediated repression, thus resulting in DHFR overexpression and methotrexate resistance. Similar to this $3^{\prime}$ UTR polymorphism, the phenomenon of alternative transcript polyadenylation (leading to shortening of 3'UTR) described above for the regulation of ABCG2 (Figure 1) [17] is another example where miRNA-mediated gene regulation can intersect with genetic variation to mediate anticancer drug resistance.

In fact, the study of 3'UTR variations is emerging as a new research avenue that holds promise for personalized pharmacotherapy [71,72]. The idea of "miRNA-pharmacogenomics" has been proposed by Bertino et al. that study the influence of genetic polymorphisms on miRNA function as a way to predict drug behavior and to improve drug efficacy [71]. Assessment of miRNA profile and 3'UTR polymorphisms in patients may thus allow personalized medicine [71].

\section{Use of miRNAs as prognostic markers for predicting chemotherapy response and/or chemoresistance: a rapidly growing field}

Along with strong evidence suggesting that miRNAs can be employed clinically as biomarkers for cancer classification, diagnosis, and prognosis $[7,73,74]$, miRNAs are also rapidly gaining popularity for predicting response to chemotherapy.

(a) In vitro evidence from cell line studies Blower et al. conducted one of the most systematic studies correlating global expression of 279 miRNAs and response to 3089 compounds in the NCI-60 drug screen cell line panel [15]. A good correlation between miRNA expression patterns and compound potency patterns was observed, thus strongly suggesting a prominent role played by miRNAs in mediating chemoresistance. When combined with gene expression and other biological data using multivariate analysis, miRNA expression profiles may help elucidate the complex mechanisms involved in chemosensitivity and chemoresistance.

(b) Evidence from clinical specimen analyses (miRNAs expressed in tumors)

Recent data suggest that miRNA expression in patient samples at baseline could predict chemotherapy and radiotherapy response. A summary of these miRNAs is compiled in Table 3. A few representative ones are elaborated below.

let-7i: In epithelial ovarian cancer, let-7i expression was reported to be significantly reduced in chemotherapy-resistant patients with epithelial ovarian cancer $(n=69, p=0.003)$ [84]. Follow up mechanistic investigation using both gain- and loss-of-function analysis revealed that reduced let$7 i$ expression in ovarian and breast cancer cells are linked to resistance to cisplatin chemotherapy [84]. However, a contradictory finding about the role of let-7i in drug resistance has also been reported [13]. By modulating let-7i expression with pre-miRNA or miRNA inhibitor transfection in the NCI-60 panel of human cancer cell lines, let-7i inhibition was found to enhance the sensitivity of A549 cells to one of their investigational anticancer agent NSC670550 [13].

miR-21: miR-21 dysregulation has been reported to be a predictor of tumor response in pancreatic cancer patients to conventional cytotoxic chemotherapeutic agents, including gemcitabine, docetaxel, temozolomide and 5-fluorouracil [85,86]. 
Table 3 Representative miRNAs from patient tumor specimens as predictive markers for treatment outcome in cancer therapy

\begin{tabular}{|c|c|c|c|}
\hline Cancer type & miRNA dysregulation & Chemotherapeutic outcome prediction & Reference \\
\hline \multirow[t]{2}{*}{ Metastatic breast cancer } & \multirow[t]{2}{*}{$\operatorname{miR}-26 \mathrm{a} \uparrow$} & $\begin{array}{l}\text { - Multivariate analysis revealed that miR-26a and CDC2 } \\
\text { (cell cycle regulator) are an optimal set of markers } \\
\text { associated with favorable outcome on tamoxifen } \\
\text { therapy, independently of traditional predictive factors } \\
\text { (menopausal status, ER \& PgR mRNA expression) }\end{array}$ & \multirow[t]{2}{*}{ [75] } \\
\hline & & $\begin{array}{l}\text { - Mechanistic analysis showed that miR-26a repressed } \\
\text { EZH2 to upregulate ER, thereby enhancing sensitivity } \\
\text { to anti-estrogen therapy }\end{array}$ & \\
\hline CRC & miR-181b $\downarrow \&$ let-7 g $\downarrow$ & $\begin{array}{l}\text { Associated with responsiveness to } 4^{\text {th }} \text { generation } \\
\text { fluoropyrimidine-based adjuvant therapy }\end{array}$ & {$[76]$} \\
\hline \multirow[t]{4}{*}{ CRC } & \multirow[t]{4}{*}{$\operatorname{miR}-215 \uparrow$} & $\begin{array}{l}\text { - miR-215 level generally downregulated in clinical } \\
\text { CRC specimen }\end{array}$ & \multirow[t]{4}{*}[77]{} \\
\hline & & $\begin{array}{l}\text { - } \uparrow \text { miR- } 215 \text { caused chemoresistance of HCT116 to } \\
\text { methotrexate and tomudex }\end{array}$ & \\
\hline & & $\begin{array}{l}\text { - No impact on treatment outcome from cisplatin and } \\
\text { doxorubicin }\end{array}$ & \\
\hline & & - High level of miR-215 was found in CRC stem cells & \\
\hline \multirow[t]{2}{*}{ Metastatic CRC } & \multirow[t]{2}{*}{ 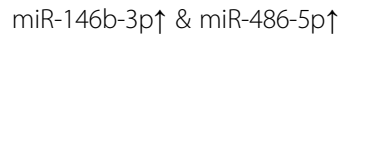 } & $\begin{array}{l}\text { - miRNAs level found to be more abundant in patients } \\
\text { with mutant KRAS }\end{array}$ & \multirow[t]{2}{*}{ [78] } \\
\hline & & $\begin{array}{l}\text { - Predictive of resistance to cetuximab (EGFR targeting } \\
\text { monoclonal antibody) }\end{array}$ & \\
\hline \multirow[t]{3}{*}{ Metastatic CRC } & $\operatorname{miR}-200 \mathrm{~b} \uparrow$ & \multirow{2}{*}{$\begin{array}{l}\text { - In KRAS mutated tumors, } \uparrow \text { miR-200b and } \downarrow \text { miR- } 143 \\
\text { were associated with a good PFS in patients on cetuximab }\end{array}$} & \multirow[t]{3}{*}{ [79] } \\
\hline & \multirow{2}{*}{ miR-143 $\downarrow$} & & \\
\hline & & $\begin{array}{l}\text { - In wild-type KRAS patients, miRNA expression did not } \\
\text { correlate with PFS in a multivariate model }\end{array}$ & \\
\hline \multirow[t]{2}{*}{ GBM } & \multirow[t]{2}{*}{$\begin{array}{l}\text { 5-miRNAs signature (miR-181d, } \\
\text { miR-518b, miR-524-5p, miR-566, } \\
\text { miR-1227) }\end{array}$} & $\begin{array}{l}\text { - Patients who had low risk scores from the 5-miRNA } \\
\text { signature and received temozolomide treatment had } \\
\text { better survival }\end{array}$ & \multirow[t]{2}{*}[80]{} \\
\hline & & $\begin{array}{l}\text { - Useful for identifying patients for more aggressive } \\
\text { therapy }\end{array}$ & \\
\hline Hepatocellular carcinoma & 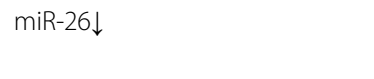 & $\begin{array}{l}\text { Lower miR-26 is associated with shorter overall survival } \\
\text { but a better response to interferon therapy }\end{array}$ & [81] \\
\hline NSCLC & $\operatorname{miR}-21 \uparrow$ & $\begin{array}{l}\text { Increased miR-21 in patients not responding to } \\
\text { platinum-based chemotherapy }\end{array}$ & [82] \\
\hline Lung cancer & miR-128b LOH & $\begin{array}{l}\text { Predictive of clinical response and prolonged survival } \\
\text { following gefitinib treatment }\end{array}$ & [83] \\
\hline Ovarian cancer & let-7i $\downarrow$ & Predictive of resistance to cisplatin & [84] \\
\hline \multirow[t]{2}{*}{ Pancreatic cancer } & \multirow[t]{2}{*}{$\operatorname{miR}-21 \uparrow$} & $\begin{array}{l}\text { - Predictive of resistance to gemcitabine, docetaxel, } \\
\text { temozolomide and 5-fluorouracil }\end{array}$ & \multirow[t]{2}{*}[85,86]{} \\
\hline & & $\begin{array}{l}\text { - Associated with shorter overall survival in the } \\
\text { metastatic and adjuvant setting }\end{array}$ & \\
\hline Pancreatic ductal adenocarcinoma & miR-10b $\downarrow$ & $\begin{array}{l}\text { Lower levels of miR-10b is associated with improved } \\
\text { response to multimodality neoadjuvant therapy. } \\
\text { Likelihood of surgical resection, delayed time to } \\
\text { metastasis and increased survival }\end{array}$ & [87] \\
\hline
\end{tabular}

Abbreviations: $\mathrm{CRC}=$ colorectal cancer; $\mathrm{EGFR}=$ epidermal growth factor receptor; $\mathrm{ER}=$ estrogen receptor; $\mathrm{GBM}=$ glioblastoma multiforme; $\mathrm{LOH}=\mathrm{loss}$ of heterozygosity; NSCLC = non-small cell lung cancer; PFS = progression-free survival; PgR = progesterone receptor.

miR-26: According to a miRNA microarray profiling study conducted in a relatively large cohort $(n=241)$ of patients with hepatocellular carcinoma, a list of tumor-related miRNAs closely associated with patient survival and treatment response to interferon was identified [81]. In particular, patients whose tumors had low miR-26 expression had shorter overall survival but a better response to interferon therapy than did patients whose tumors had high expression of the miRNA. miR-128b: In a cohort of 58 non-small-cell lung cancer patients, miR-128b loss of heterozygosity 
(LOH) in the tumors was found to correlate with clinical response and prolonged survival following treatment with gefitinib [83]. Mechanistic investigation in NSCLC cell lines using miR-128b mimics or inhibitors confirmed that EGFR (the molecular target of gefitinib) is specifically regulated by the miRNA. LOH of chromosome 3p is a well-known and early genetic abnormality in lung cancer. Since miR-128b resides on the 3p22 locus, the aforementioned finding about the LOH of miR-128b could provide a functional link between a common genetic abnormality in lung cancer (i.e. loss of 3p22) and the frequent overexpression of EGFR in NSCLC patients. The clinical significance is that miR-128b may be used as a useful prognostic marker for selecting patient candidates to receive and benefit the most from EGFR tyrosine kinase inhibitors.

(c) Circulating miRNAs as non-invasive biomarkers for predicting chemotherapy response

In recent years, circulating miRNAs, refering to the miRNAs present in cell-free body fluids such as plasma, serum, urine and saliva, etc, have been exploited for use as biomarkers in various disease states. These circulating miRNAs are bound to proteins including argonaute2 [88] and high density lipoprotein [89], or are encapsulated in exosomes [90], which render them highly resistant to RNase activity. Therefore, they can be reliably measured by the highly sensitive and relatively inexpensive method of quantitative polymerase chain reaction (qPCR). Moreover, the ease of access, minimal invasiveness and the possibiliy of repeated sampling of circulating miRNAs have also made them ideal candidates for use as biomarkers. Due to space limitation, we have highlighted a few representative circulating miRNAs that have been reported as useful predictive biomarkers for chemotherapy response (Table 4).

While a number of circulating miRNAs have been identified as useful biomarkers for predicting treatment response to chemotherapy and/or surgery, the detailed mechanism is usually not determined. It remains to be determined as to whether the circulating miRNAs are actively released by surviving cancer cells or derived from the dead cancer cells. Interestingly, in prostate cancer, Lucotti et al. has nicely demonstrated that cytotoxic treatment of DU-145 prostate cancer cells by fludarabine enhanced the release of a list of exosomesassociated prostate cancer secretary (PCS)-miRNAs, with the exception of miR-485-3p, which is retained by surviving cancer cells [97]. Follow-up mechanistic investigation revealed that the intracellular retention of miR-485-3p downregulate the transcriptional repressor NF-Y, and thus allowing the overexpression of drug resistance genes (including TOP2A, MDR1 and cyclin B2 pro-suvival genes) to mediate resistance [97].

In summary, tumoral miRNA expression at diagnosis may help predict the patients' response to chemotherapy and also provide insights about mechanism of chemotherapy resistance. It may also provide guidance for rational and personalized chemotherapy selection. To this end, circulating miRNA as a novel prognostic or predictive tool is also rapidly gaining popularity $[100,101]$ because of the non-invasive nature of the detection method. Moreover, miRNA-based profiling also has another added advantage over conventional mRNA-based methods. MiRNAs in formalin-fixed tissues, blood plasma and serum are known to be remarkably more stable than mRNAs to endogenous RNase digestion [102], thereby enabling their reliable extraction and analysis from patient specimens.

\section{MiRNAs as druggable targets and miRNA-based therapeutics for circumvention of anticancer drug resistance}

(a) MiRNA-based therapeutics Since miRNA expression is often dysregulated in cancer cells, approaches that modulate miRNA activity could potentially produce specific anti-cancer effect. With the advancement in technology, modulation of endogenous miRNA levels can now be achieved in several ways. Oncogenic miRNAs can be targeted for downregulation using various modified antisense oligonucleotides (also known as antagomirs) to their precursor or mature forms, whereas tumor suppressive miRNAs may be directly upregulated by using synthetic miRNA mimics (including siRNA-like oligoribonucleotide duplex and chemically modified oligoribonucleotide [103]) for an anti-cancer effect. In particular, antagomirs, with 2'-O-methylation or locked nucleic acid modifications, have drawn a lot of attention. Successful in vivo silencing of miRNA has been achieved by their systematic administration through tail vein injections into mice $[104,105]$. On the other hand, a few proof-of-concept studies using artificial synthetic miRNAs have been successfully performed to target a few oncogenes and produce anticancer effect [106-108]. A list of representative miRNAs as potential molecular targets for cancer therapy is compiled in Table 5. 
Table 4 Representative circulating miRNAs reported to predict response to chemotherapy and/or surgery

\begin{tabular}{|c|c|c|c|c|}
\hline Cancer type & $\begin{array}{l}\text { miRNA dysregulation } \\
\text { associated with poor } \\
\text { response }\end{array}$ & Sample type & Significance & Reference \\
\hline Breast & $\uparrow \mathrm{miR}-125 \mathrm{~b}$ & Serum & $\begin{array}{l}\text { Increased in patiens not responding to } \\
\text { neoadjuvant chemotherapy }\end{array}$ & [91] \\
\hline \multirow[t]{4}{*}{ Breast } & \multirow[t]{4}{*}{$\uparrow \operatorname{miR}-210$} & \multirow[t]{4}{*}{ Plasma } & $\begin{array}{l}\text { Lower miR-210 plasma levels are associated } \\
\text { with }\end{array}$ & \multirow[t]{4}{*}{ [92] } \\
\hline & & & $\begin{array}{l}\text { - complete response to trastuzumab (HER-2 } \\
\text { targeted monoclonal antibody) }\end{array}$ & \\
\hline & & & - surgical removal of tumor & \\
\hline & & & - lack of tumor metastasis to lymph nodes & \\
\hline \multirow[t]{2}{*}{ Colorectal (CRC) } & \multirow[t]{2}{*}{$\uparrow \operatorname{miR} 17-3 p$} & \multirow[t]{2}{*}{ Plasma } & - Elevated in both CRC tissue and plasma & \multirow[t]{2}{*}{ [93] } \\
\hline & & & $\begin{array}{l}\text { - Lower level detected in post-operative } \\
\text { plasma is associated with responsiveness } \\
\text { to surgery }\end{array}$ & \\
\hline \multirow[t]{3}{*}{ Colorectal (CRC) } & \multirow[t]{3}{*}{$\uparrow \operatorname{miR}-29 a$} & \multirow[t]{3}{*}{ Serum } & - Elevated in both CRC tissue and plasma & \multirow[t]{3}{*}{ [93] } \\
\hline & & & $\begin{array}{l}\text { - Help differentiate CRC from gastric cancer, } \\
\text { inflammatory bowel disease and no tumor } \\
\text { controls }\end{array}$ & \\
\hline & & & $\begin{array}{l}\text { - Lower level detected in post-operative plasma } \\
\text { is associated with responsiveness to surgery }\end{array}$ & \\
\hline Colorectal (CRC) & $\begin{array}{l}\uparrow \operatorname{miR}-27 b, \text { miR-148a, } \\
\text { miR-326 }\end{array}$ & Plasma & $\begin{array}{l}\text { Elevated in patients with metastatic CRC not } \\
\text { responding to } 5 \text {-fluouracil and oxaliplatin-based } \\
\text { chemotherapy }\end{array}$ & [94] \\
\hline Lung & $\uparrow \operatorname{miR}-21$ & Plasma & $\begin{array}{l}\text { Increased; associated with resistance to } \\
\text { platinum-based chemotherapy }\end{array}$ & [95] \\
\hline \multirow[t]{2}{*}{ Non-Hodgkin's lymphoma (NHL) } & \multirow[t]{2}{*}{$\downarrow$ miR-92a } & \multirow[t]{2}{*}{ Plasma } & $\begin{array}{l}\text { - Remarkably lower in NHL patients }(<5 \%) \text { than } \\
\text { in healthy subjects }\end{array}$ & \multirow[t]{2}{*}{ [96] } \\
\hline & & & $\begin{array}{l}\text { - The very low plasma level of miR-92a increased } \\
\text { in complete response phase but became lower } \\
\text { again in the relapse phase }\end{array}$ & \\
\hline \multirow[t]{3}{*}{ Prostate } & \multirow[t]{3}{*}{$\begin{array}{l}\uparrow \text { Prostate cancer secretary } \\
\text { (PCS)-miRNAs }\end{array}$} & \multirow[t]{3}{*}{ Plasma/serum } & $\begin{array}{l}\text { - It is not clear whether circulating miRNAs are } \\
\text { actively released by live cancer cells or derived } \\
\text { from dead cancer cells. }\end{array}$ & \multirow[t]{3}{*}{ [97] } \\
\hline & & & $\begin{array}{l}\text { - In vitro cytotoxic treatment of DU-145 cells } \\
\text { enhanced the release of exosomes-associated } \\
\text { PCS-miRNAs, with the exception of miR-485-3p, } \\
\text { which is retained by surviving cancer cells. }\end{array}$ & \\
\hline & & & $\begin{array}{l}\text { - The intracellular retention of miR-485-3p was } \\
\text { shown to downregulate the transcriptional } \\
\text { repressor NF-Y, thus allowing the overexpression } \\
\text { of a few drug resistance genes (including TOP2A, } \\
\text { MDR1, and cyclin B2 pro-survival genes) }\end{array}$ & \\
\hline \multirow[t]{2}{*}{ Prostate } & \multirow[t]{2}{*}{$\uparrow \operatorname{miR}-21$} & \multirow[t]{2}{*}{ Serum } & - Increased in hormone-refractory prostate cancer & \multirow[t]{2}{*}{ [98] } \\
\hline & & & $\begin{array}{l}\text { - Associated with resistance to docetaxel-based } \\
\text { chemotherapy }\end{array}$ & \\
\hline \multirow[t]{4}{*}{ Advanced renal cell carcinoma } & $\uparrow \operatorname{miR}-192$ & \multirow{4}{*}{$\begin{array}{l}\text { Peripheral blood } \\
\text { samples }\end{array}$} & - Models predicting poor and prolonged response & \multirow[t]{4}{*}[99]{} \\
\hline & \multirow{3}{*}{$\uparrow \operatorname{miR}-193 a-3 p$} & & d & \\
\hline & & & $\begin{array}{l}\text { - Ontology analyses revealed relevance to } \\
\text { cancer-related pathways (angiogenesis and } \\
\text { apoptosis) }\end{array}$ & \\
\hline & & & $\begin{array}{l}\text { - miRNA expression signatures may be used to } \\
\text { identify patients who may benefit the most from } \\
1^{\text {st }} \text { line therapy with sunitinib }\end{array}$ & \\
\hline
\end{tabular}


Table 5 MiRNAs as targets for cancer therapy

\begin{tabular}{|c|c|c|c|}
\hline Cancer type & miRNA target and its role in cancer & Delivery system to modulate the miRNA in vivo* & Reference \\
\hline Breast cancer & miR-34a - Tumor suppressor & Cationic liposomes & [109] \\
\hline Glioblastoma & miR-145 - Tumor suppressor & Adenoviruses & [110] \\
\hline Glioblastoma & miR-221-222 - Oncogene & Adenoviruses & [111] \\
\hline \multirow{2}{*}{$\begin{array}{l}\text { Glioblastoma } \\
\text { Multiforme (GBM) }\end{array}$} & \multirow{2}{*}{$\begin{array}{l}\text { miR-9 - promote expression of P-gp } \\
\text { (a multidrug resistance efflux transporter) }\end{array}$} & - Mesenchymal stem cell-derived exosomes & \multirow[t]{2}{*}{ [112] } \\
\hline & & $\begin{array}{l}\text { - To deliver anti-miR-9 to temozolomide-resistant } \\
\text { GBM to reduce P-gp expression for resistance reversal }\end{array}$ & \\
\hline $\begin{array}{l}\text { Hepatocellular } \\
\text { carcinoma }\end{array}$ & miR-26 - Tumor suppressor & Adenoviruses & [113] \\
\hline Lung cancer & let-7 - Tumor suppressor & Adenoviruses & [114] \\
\hline Lung cancer & miR-34a - Tumor suppressor & Cationic liposomes & [115] \\
\hline Lymphoma & miR-155 - Oncogene & Polymer-based nanoparticles & [116] \\
\hline Medulloblastoma & $\begin{array}{l}\text { miR-17 } 92 \text { cluster family - Sonic } \\
\text { Hedgehog signaling }\end{array}$ & $\begin{array}{l}\text { 8-mer seed-targeting locked nucleic acid } \\
\text { (LNA)-modified anti-miR oligonucleotides } \\
\text { (nude mice) }\end{array}$ & {$[117]$} \\
\hline Pancreatic cancer & miR-21 - Oncogene & Lentiviruses & [118] \\
\hline
\end{tabular}

* The miRNA target can be modulated by anti-miRNA oligonucleotides or miRNA-expressing constructs (delivered by viral or non-viral vectors).

(b) Potential miRNA targets for resistance circumvention

Although the use of miRNAs for cancer chemotherapy has not yet been realized in clinical trials, it has recently been demonstrated in tissue culture systems that miRNA-targeted therapy may be useful in combination with conventional chemo-radiotherapy to sensitize the cancer cells. Table 6 summarizes a few representative miRNA-modulatory approaches to circumvent anticancer drug resistance. let-7 overexpression has been shown to confer radiosensitivity in lung cancer cell lines [123]. Inhibition of miR-21 and miR-200b was reported to enhance the sensitivity of cholangiocarcinomas to gemcitabine chemotherapy [120]. MiR-21 is of particular interest, which is overexpressed in most cancer types analyzed [124].
A landmark study has been reported to illustrate the phenomenon of "oncomiR addiction" in an in vivo model of miR-21-induced pre-B-cell lymphoma [119]. Most intriguingly, complete tumor regression can be achieved in a few days when miR-21 was inactivated by the antisense strategy in vivo. Given that aberrant miR-21 expression is known to reduce sensitivity of cancer cells to a number of anticancer drugs including tamoxifen, gemcitabine, doxorubicin and docetaxel [124], inactivating miR-21 may represent a novel strategy for cancer drug resistance circumvention. Most recently, a novel approach to deliver functional anti-miR-9 by mesenchymal stem cell-derived exosomes to glioblastoma multiforme (GBM) cells has been reported to circumvent P-gp-mediated resistance to temozolomide [112]. Site-directed

Table 6 Novel approaches to circumvent chemoresistance by modulating unique miRNAs

\begin{tabular}{|c|c|c|c|c|}
\hline Cancer type & $\begin{array}{l}\text { miRNA targeted for } \\
\text { inhibition }\end{array}$ & Type of resistance circumvented & $\begin{array}{l}\text { Delivery system for modulation of } \\
\text { miRNAs }\end{array}$ & Reference \\
\hline B-cell lymphoma & miR-21 - oncomiR addiction & - & Antisense strategy & {$[119]$} \\
\hline Cholangiocarcinomas & miR-21 \& miR-200b & $\begin{array}{l}\text { Gecitabine resistance mediated by } \\
\text { PTEN-dependent activation of PI3K } \\
\text { signaling }\end{array}$ & $\begin{array}{l}\text { Transfection with miRNA-specific antisense } \\
\text { oligonucleotides }\end{array}$ & {$[120]$} \\
\hline $\begin{array}{l}\text { Glioblastoma } \\
\text { Multiforme (GBM) }\end{array}$ & $\begin{array}{l}\text { miR-9 - indirectly promoting } \\
\text { expression of the MDR } \\
\text { transporter P-gp }\end{array}$ & $\begin{array}{l}\text { P-gp-mediated resistance to } \\
\text { temozolomide }\end{array}$ & $\begin{array}{l}\text { - Mesenchymal stem cell-derived exosomes } \\
\text { - To deliver anti-miR-9 to temozolomide- } \\
\text { resistant GBM to reduce P-gp expression for } \\
\text { resistance reversal }\end{array}$ & {$[112]$} \\
\hline GBM & miR-21 & $\begin{array}{l}\text { - Temozolomide } \\
\text { - Enhance apoptosis }\end{array}$ & Transfection with anit-miR-21 oligonucleotide & {$[121]$} \\
\hline Lung cancer & miR-92b & $\begin{array}{l}\text { Cisplatin resistance mediated by } \\
\text { downregulation of the tumor } \\
\text { suppressor gene PTEN }\end{array}$ & $\begin{array}{l}\text { Transfection with anti-miR-92b } \\
\text { oligonucleotide }\end{array}$ & [122] \\
\hline
\end{tabular}


targeted delivery of the anti-miR-9 to GBM cells was achieved because mesenchymal stem cells are able to migrate preferentially to the brain.

(c) Therapeutic drugs altering miRNA profile in cancer cells

Apart from exhibiting aberrant expression of a few miRNAs, human cancers are in fact characterized by impaired miRNA processing and global miRNA dysregulation [125]. It has been recently shown that miRNA expression can be differentially altered by xenobiotic drugs in difference human cell lines [126]. The drugs identified are not necessarily anticancer drugs. The practical implication is that they could be safely administered with other conventional anticancer drugs in an attempt to reverse miRNA-mediated drug resistance. Along this line of investigation, the fluoroquinolone class of antibiotics has been shown to enhance RNA interference and promote miRNA processing $[127,128]$. This may represent a novel approach to modulate multiple miRNAs simultaneously or to restore the global miRNA expression (i.e. micRNAome) to provide a cancer-specific growth inhibitory effect. It has also been proposed that specific class of drugs might be screened for their effects on shifting the miRNA expression profile of a cancer cell towards that of a normal tissue [129]. To this end, the SM2miR database has been established to provide a fairly comprehensive respository about the influences of small molecules on miRNA expression, which could promote the futher development of miRNA-targeting therapeutics [130]. Calin et al. has proposed structure-based approaches (such as molecular docking) to identify compounds that may target specific miRNAs [131]. However, three-dimemsional structure prediction of miRNA still remains a challenge. There has also been attempts to identify small molecules targeting specific miRNAs in human cancers based on transcriptional responses [132]. As more is discovered in this research area, the specific modulation of miRNAs by therapeutic drugs may become feasible in the future.

(d) Off-target effects

Each miRNA typically targets up to hundreds of transcripts directly or indirectly, and multiple miRNAs can target a given gene. It follows that miRNAs are also tied to some tightly regulated gene expression networks in normal cells. The therapeutic outcome of a miRNA-targeted chemotherapy or resistance reversal regimen may thus depend on the number of miRNA targets and the affinities for each of these targets that are expressed in a given tumor microenvironment. It could be difficult to rule out the by-stander off-target effects, if any. Moreover, an appropriate method to deliver the effective miRNA mimic/ antagomir to the right cell type must also be considered in order to prevent unwanted side effects. Indeed, a fatal side effect as a result of saturation of miRNA pathways has been reported in an animal study [133]. It appears that these hurdles have to be overcome before an effective miRNA-targeted strategy can be realized for circumvention of anticancer drug resistance in cancer patients.

\section{Conclusions}

The emerging role of miRNAs as regulators of gene expression, and their dysregulation in human cancer has provided opportunities for their therapeutic application in the capacity of cancer detection, diagnosis and prognosis prediction. Selective targeting of some miRNAs may be useful in enhancing chemosensitivity, and may have future applications in modulating therapeutic response to molecular targeted chemotherapeutics in selected cancer subtypes. A better understanding about the complex regulatory pathways that control miRNAs function and their tumor-specific effect will be needed in order to fully realize the promise of miRNAs in cancer diagnosis, chemotherapy and drug resistance circumvention.

\section{Abbreviations \\ ABCG2/BCRP: Breast cancer resistance protein; $A B C$ transporters: ATP-binding cassette transporters; CSC: Cancer stem cell; DHFR: Dihydrofolate reductase; EGFR: Epidermal growth factor receptor; EMT: Epithelial-to-mesenchymal transition; GSH: Glutathione; HuES: Human embryonic stem cell; LOH: Loss of heterozygosity; MDR-1/ABCB1: P-glycoprotein; MeCP2: Methyl CpG binding protein 2; miRNA/miR: microRNA; MRP-1/ABCC1: Multidrug resistance associated protein 1; PcG: Polycomb group protein; Pt: Platinum; PTEN: Phosphatase and tensin homolog; SnoRNA: Small nucleolar RNA; SP: Side population; $3^{\prime} U T R$ : $3^{\prime}$ untranslated region.}

Competing interests

The author declares that he has no competing interests.

\section{Author's contributions}

KKT completed the final draft and approved the manuscript.

\section{Acknowledgements}

We acknowledge the researchers who have contributed to the understanding of miRNA-mediated regulation of various MDR pathways and whose works have not been cited here because of space limitations. The work by the author described in this review was supported in part by a Direct Grant (2041532) provided by the Medicine Panel of the Chinese University of Hong Kong to Kenneth To.

Received: 15 September 2013 Accepted: 16 December 2013 Published: 20 December 2013

\section{References}

1. Goldman B: Multidrug resistance: can new drugs help chemotherapy score against cancer? J Natl Cancer Inst 2003, 95:255-257.

2. Gottesman MM, Fojo T, Bates SE: Multidrug resistance in cancer: role of ATP-dependent transporters. Nat Rev Cancer 2002, 2:48-58.

3. Bartel DP: MicroRNAs: target recognition and regulatory functions. Cell 2009, 136:215-233. 
4. Lim LP, Glasner ME, Yekta S, Burge CB, Bartel DP: Vertebrate microRNA genes. Science 2003, 299:1540.

5. Lewis BP, Burge CB, Bartel DP: Conserved seed pairing, often flanked by adenosines, indicates that thousands of human genes are microRNA targets. Cell 2005, 120:15-20.

6. Xie X, Lu J, Kulbokas EJ, et al: Systematic discovery of regulation motifs in human promoters and $3^{\prime} \mathrm{UTR}$ s by comparison of several mammals. Nature 2005, 434:338-345.

7. Lu J, Getz G, Miska EA, et al: MicroRNA expression profiles classify human cancers. Nature 2005, 435:834-838.

8. Esquela-Kerscher A, Slack FJ: Oncomirs - microRNAs with a role in cancer. Nat Rev Cancer 2006, 6:259-269.

9. Hammond SM: MicroRNAs as tumor suppressors. Nat Genet 2007, 39:582-583.

10. Tricoli JV, Jacobson JW: MicroRNA: potential for cancer detection, diagnosis, and prognosis. Cancer Res 2007, 67:4553-4555.

11. Blenkiron C, Miska EA: miRNAs in cancer: approaches, aetiology, diagnostics and therapy. Hum Mol Genet 2007, 16:R106-R113.

12. Fojo T: Multiple paths to a drug resistance phenotype: mutations, translocations, deletions and amplification of coding genes or promoter regions, epigenetic changes and microRNAs. Drug Resist Update 2007, 10:59-67.

13. Blower PE, Chung JH, Verducci JS, et al: MicroRNAs modulate the chemosensitivity of tumor cells. Mol Cancer Ther 2008, 7:1-9.

14. Kovalchuk O, Fikowski J, Meservy J, et al: Involvement of microRNA-451 in resistance of the MCF-7 breast cancer cells to chemotherapeutic drug doxorubicin. Mol Cancer Ther 2008, 7:2152-2159.

15. Blower PE, Verducci JS, Lin $S$, et al: MicroRNA expression profiles for the NCl-60 cancer cell line panel. Mol Cancer Ther 2007, 6:1483-1491.

16. To KK, Zhan Z, Litman T, Bates SE: Regulation of ABCG2 expression at the 3'untranslated region of its mRNA through modulation of transcript stability and protein translation by a putative microRNA in the S1 colon cancer cell line. Mol Cell Biol 2008, 28:5147-5161.

17. To KK, Robey RW, Knutsen T, Zhan Z, Ried T, Bates SE: Escape from hsa-miR-519c enables drug-resistant cells to maintain high expression of ABCG2. Mol Cancer Ther 2009, 8:2959-2968.

18. Pan YZ, Morris ME, Yu AM: MicroRNA-328 negatively regulates the expression of breast cancer resistance protein (BCRP/ABCG2) in human cancer cells. Mol Pharmacol 2009, 75:1374-1379.

19. Xia $L$, Zhang $D, D u R$, et al: MiR-15b and miR-16 modulate multidrug resistance by targeting BCL2 in human gastric cancer cells. Int J Cancer 2008, 123:372-379.

20. Mishra PJ, Humeniuk R, Longo Sorbello GS, Banerjee D, Bertino JR: A miR-24 microRNA binding-site polymorphism in dihydrofolate reductase gene leads to methotrexate resistance. Proc Natl Acad Sci USA 2007, 104:13513-13518.

21. Yang $H$, Kong $W$, He $L$, et al: MicroRNA expression profiling in human ovarian cancer: miR-214 induces cell survival and cisplatin resistance by targeting PTEN. Cancer Res 2008, 68:425-433.

22. Allen $\mathrm{KE}$, Weiss $\mathrm{GJ}$ : Resistance may not be futile: microRNA biomarkers for chemoresisatnce and potential therapeutics. Mol Cancer Ther 2010 9:3126-3136.

23. Li Z, Hu S, Wang J, et al: MiR-27a modulates MDR1/P-glycoprotein expression by targeting HIPK2 in human ovarian cancer cells. Gynecol Oncol 2010, 119:125-130

24. Zhu H, Wu H, Liu X, et al: Role of microRNA miR-27a and miR-451 in the regulation of MDR1/P-glycoprotein expression in human cancer cells. Biochem Pharmacol 2008, 76:582-588.

25. Xu Y, Xia F, Ma L, et al: MicroRNA-122 sensitizes HCC cancer cells to adriamycin and vincristine through modulating expression of MDR and inducing cell cycle arrest. Cancer Lett 2011, 310:160-169.

26. Hong $L$, Han $Y$, Zhang $H$, et al: The prognostic and chemotherapeutic value of miR-296 in esophageal squamous cell carcinoma. Ann Surg 2010, 251:1056-1063.

27. Bao L, Hazari S, Mehra S, Kaushal D, Moroz K, Dash S: Increased expression of P-glycoprotein and doxorubicin chemoresistance of metastatic breast cancer is regulated by miR-298. Am J Pathol 2012, 180:2490-2503.

28. Boyerinas $B$, Park SM, Murmann AE, et al: Let-7 modulates required resistance of ovarian cancer to Taxanes via IMP-1-mediated stabilization of multidrug resistance 1. Int J Cancer 2012, 130:1787-1797.
29. Liang Z, Wu H, Xia J, et al: Involvement of miR-326 in chemotherapy resistance of breast cancer through modulating expression of multidrug resistance-associated protein 1. Biochem Pharmacol 2010, 79:817-824.

30. Pan YZ, Zhou A, Hu Z, Yu AM: Small nucleolar RNA-derived microRNA hsa-miR-1291 modulates cellular drug disposition through direct targeting of $A B C$ transporter ABCC1. Drug Metab Dispos 2013: doi: 10.1124/dmd.113.052092.

31. Xu K, Liang X, Shen K, et al: MiR-297 modulates multidrug resistance in human colorectal carcinoma by down-regulating MRP-2. Biochem J 2012, 446:291-300.

32. Jeon HM, Sohn YW, Oh SY, et al: ID4 imparts chemoresistance and cancer stemness to glioma cells by derepressing miR-9*-mediated suppression of SOX2. Cancer Res 2011, 71:3410-3421.

33. Turrini E, Haenisch S, Laechelt S, Diewock T, Bruhn O, Cascorbi I: MicroRNA profiling in K-562 cells under imatinib treatment: influence of miR-212 and miR-328 on ABCG2 expression. Pharmacogenet Genomics 2012, 22:198-205.

34. $X u X T, X u Q$, Tong $\lrcorner L$, et al: MicroRNA expression profiling identifies miR-328 regulates cancer stem cell-like SP cells in colorectal cancer. Br J Cancer 2012, 106:1320-1330.

35. Pan YZ, Seigel GM, Hu ZH, Huang M, Yu AM: Breast cancer resistance protein BCRP/ABCG2 regulatory microRNAs (hsa-miR-328, $-519 \mathrm{c},-520 \mathrm{~h}$ ) and their differential expression in stem-like $A B C G 2+$ cancer cells. Biochem Pharmacol 2011, 81:783-792.

36. Liao R, Sun J, Zhang $L$, et al: MicroRNAs play a role in the development of human hematopoietic stem cells. J Cell Biochem 2008, 104:805-817.

37. Wang $F$, Xue $X$, Wei J, et al: hsa-miR-520 h downregulates ABCG2 in pancreatic cancer cells to inhibit migration, invasion, and side populations. Br J Cancer 2010, 103:567-574.

38. Jiao X, Zhao L, Ma M, Bai X, He M, Yan Y, Wang Y, Chen Q, Zhao X, Zhou M, Cui Z, Zheng Z, Wang E, Wei M: MiR-181a enahances drug sensitivity in mitoxantrone-resistant breast cancer cells by targeting breast cancer resistance protein (BCRP/ABCG2). Breast Cancer Res Treat 2013, 139:717-730.

39. Ma MT, He M, Wang Y, Jiao XY, Zhao L, Bai XF, Yu ZJ, Wu HZ, Sun ML, Song ZG, Wei MJ: MiR-487a resensitizes mitoxantrone (MX)-resistant breast cancer cells (MCF-7/MX) to MX by targeting breast cancer resistance protein (BCRP/ABCG2). Cancer Lett 2013, 339:107-115.

40. Xu K, Liang X, Cui D, Wu Y, Shi W, Liu J: miR-1915 inhibits BCl-2 to moderate multidrug resistance by increasing drug-sensitivity in human colorectal carcinoma cells. Mol Carcinog 2013, 52:70-78.

41. Kojima K, Fujita Y, Nozawa Y, Deguchi T, Ito M: MiR-34a attenuates paclitaxel-resistance of hormone-refractory prostat cancer PC3 cells through direct and indirect mechanisms. Prostate 2010, 70:1501-1512.

42. Liu S, Tetzlaff MT, Cui R, Xu X: miR-200c inhibits melanoma progression and drug resistance through down-regulation of Bmi-1. Am J Pathol 2012, 181:1823-1835.

43. Puhr M, Hoefer J, Schafer G, et al: Epithelial-to-mesenchymal transition leads to docetaxel resistance in prostate cancer and is mediated by reduced expression of miR-200c and miR-205. Am J Pathol 2012, 181:2188-2201.

44. Cochrane DR, Spoelstra NS, Howe EN, Nordeen SK, Richer JK: MicroRNA-200c mitigates invasiveness and restores sensitivity to microtubule-targeting chemotherapeutic agents. Mol Cancer Ther 2009, 8:1055-1066.

45. Robey RW, Polgar O, Deeken J, To KW, Bates SE: ABCG2: determining its relevance in clinical drug resistance. Cancer Metastasis Rev 2007, 26:39-57.

46. Knutsen T, Rao VK, Ried T, et al: Amplification of 4q21-q22 and the MXR gene in independently derived mitoxantrone-resistant cell lines. Genes Chromosomes Cancer 2000, 27:110-116.

47. Nakanishi T, Bailey-Dell KJ, Hassel BA, et al: Novel 5'untranslated region variants of BCRP mRNA are differentially expressed in drug-selected cancer cells and in normal human tissues: implications for drug resistance, tissue-specific expression, and alternative promoter usage. Cancer Res 2006, 66:5007-5011.

48. Krishnamurthy P, Ross DD, Nakanishi T, et al: The stem cell marker Bcrp/ ABCG2 enhances hypoxic cell survival through interactions with heme. J Biol Chem 2004, 279:24218-24225.

49. Guhaniyogi J, Brewer G: Regulation of mRNA stability in mammalian cells. Gene 2001, 265:11-23.

50. Di Giammartino DC, Nishida K, Manley JL: Mechanisms and consequences of alternative polyadenylation. Mol Cell 2011, 43:853-866. 
51. Tian B, Hu J, Zhang H, Lutz CS: A large-scale analysis of mRNA polyadenylation of human and mouse genes. Nucleic Acids Res 2005, 33:201-212.

52. Sandberg R, Neilson JR, Sarma A, Sharp PA, Burge CB: Proliferating cells express mRNAs with shortened 3'untranslated regions and fewer microRNA target sites. Science 2008, 320:1643-1647.

53. Ji Z, Tian B: Reprogramming of 3'untranslated regions of mRNAs by alternative polyadenylation in generation of pluripotent stem cells from different cell types. PLoS One 2009, 4:e8419.

54. Mayr C, Bartel DP: Widespread shortening of 3'UTR by alternative cleavage and polyadenylation activates oncogenes in cancer cells. Cell 2009, 138:673-684.

55. Shepard PJ, Choi EA, Lu J, Flanagan LA, Hertel KJ, Shi Y: Complex and dynamic landscape of RNA polyadenylation revealed by PAS-Seq. RNA 2011, 17:761-772.

56. Legendre M, Ritchie W, Lopez F, Gautheret D: Differential repression of alternative transcripts: a screen for miRNA targets. PLoS Comput Biol 2006, 2:e43.

57. Apati A, Orban TI, Varga N, et al: High level functional expression of the ABCG2 multidrug transporter in undifferentiated human embryonic stem cells. Biochim Biophys Acta 2008, 1778:2700-2709.

58. Juliano RL, Ling V: A surface glycoprotein modulating drug permeability in Chinese hamster ovary cell mutants. Biochim Biophys Acta 1976, 455:152-162.

59. Ambudkar SV, Kimchi-Sarfaty C, Sauna ZE, Gottesman MM: P-glycoprotein: from genomics to mechanism. Oncogene 2003, 22:7468-7485.

60. Zhou SF, Wang LL, Di YM, et al: Substrates and inhibitors of human multidrug resistance associated proteins and the implications in drug development. Curr Med Chem 2008, 15:1981-2039.

61. Sparanese D, Lee CH: CRD-BP shields c-myc and MDR-1 RNA from endonucleolytic attack by a mammalian endoribonuclease. Nucleic Acids Res 2007, 35:1209-1221.

62. Boyerinas B, Park SM, Shomron N, et al: Identification of let-7-regulated oncofetal genes. Cancer Res 2008, 68:2587-2591.

63. Nardinocchi L, Puca R, Sacchi A, D'Orazi G: Inhibition of HIF-1alpha activity by homeodomain-interacting protein kinase-2 correlates with sensitization of chemoresistant cells to undergo apoptosis. Mol Cancer 2009, 8:1.

64. Chekhun VF, Lukyanova NY, Kovalchuk O, Tryndyak VP, Pogribny IP: Epigenetic profiling of multidrug-resistant human MCF-7 breast adenocarcinoma cells reveals novel hyper- and hypomethylated targets. Mol Cancer Ther 2007, 6:1089-1098.

65. Fabbri M, Garzon R, Cimmino A, et al: MicroRNA-29 family reverts aberrant methylation in lung cancer by targeting DNA methyltransferases $3 \mathrm{~A}$ and 3B. Proc Natl Acad Sci USA 2007, 104:15805-15810.

66. Klein ME, Lioy DT, Ma L, Lmpey S, Mandel G, Goodman RH: Homeostatic regulation of $\mathrm{MeCP} 2$ expression by a CREB-induced microRNA. Nat Neurosci 2007, 10:1513-1514.

67. Nies AT, Jedlitschky G, Konig J, et al: Expression and immunolocalization of the multidrug resistance proteins, MRP1-MRP6 (ABCC1-ABCC6), in human brain. Neuroscience 2004, 129:349-360.

68. Garofalo M, Di Leva G, Romano G, et al: miR-221\&222 regulate TRAIL resistance and enhance tumorigenicity through PTEN and TIMP3 downregulation. Cancer Cell 2009, 16:498-509.

69. Vinciguerra M, Sgroi A, Veyrat-Durebex C, Rubbia-Brandt L, Buhler LH, Foti M: Unsaturated fatty acids inhibit the expression of tumor suppressor phosphatase and tensin homolog (PTEN) via microRNA-21 up-regulation in hepatocytes. Hepatology 2009, 49:1176-1184.

70. Saunders MA, Liang H, Li WH: Human polymorphism at microRNAs and microRNA target sites. Proc Natl Acad Sci USA 2007, 104:3300-3305

71. Bertino JR, Banerjee D, Mishra PJ: Pharmacogenomics of microRNA: a miRSNP towards individualized therapy. Pharmacogenomics 2007, 8:1625-1627.

72. Mishra PJ, Banerjee D, Bertino JR: MiRSNPs or MiR-polymorphisms, new players in microRNA mediated regulation of the cell. Cell Cycle 2008, 7:853-858.

73. Yanaihara N, Caplen N, Bowman E, et al: Unique microRNA molecular profiles in lung cancer diagnosis and prognosis. Cancer Cell 2006, 9:189-198.

74. Mitchell PS, Parkin RK, Kroh EM, et al: Circulating microRNAs as stable blood-based markers for cancer detection. Proc Natl Acad Sci USA 2008, 105:10513-10518.
75. Jansen MP, Reijm EA, Sieuwerts AM, Ruigrok-Ritstier K, Look MP, Rodriguez-Gonzalez FG, Heine AA, Martens JW, et al: High miR-26a and low $\mathrm{CDC} 2$ levels associate with decreased EZH2 expression and with favorable outcome on tamoxifen in metastatic breast cancer. Breast Cancer Res Treat 2012, 133:937-947.

76. Nakajima G, Hayashi K, Xi Y, Kudo K, Uchida K, Takasaki K, Yamamoto M, Ju J: Non-coding microRNAs hsa-let-7 $g$ and hsa-miR-181b are associated with chemoresponse to S-1 in colon cancer. Cancer Genomics Proteomics 2006, 3:317-324.

77. Song B, Wang Y, Titmus MA, Botchkina G, Formentini A, Kornmann M, Ju J: Molecular mechanism of chemoresistance by miR-215 in osteosarcoma and colon cancer cells. Mol Cancer 2010, 9:96.

78. Ragusa M, Majorana A, Statello L, Maugeri M, Salito L, Barbagallo D, Guglielmino MR, Duro LR, Angelica R, Caltabiano R, Biondi A, Di Vita M, Privitera $G$, et al: Specific alterations of microRNA transcriptome and global network structure in colorectal carcinoma after cetuximab treatment. Mol Cancer Ther 2010, 9:3396-3409.

79. Mekenkamp LJ, Tol J, Dijkstra JR, de Krijger I, et al: Beyond KRAS mutation status: influence of KRAS copy number status and microRNAs on clinical outcome to cetuximab in metastatic colorectal cancer patients. BMC Cancer 2012, 12:292.

80. Zhang W, Zhang J, Yan W, You G, Bao Z, Li S, et al: Whole-genome microRNA expression profiling identifies a 5-microRNA signature as a prognostic biomarker in Chinese patients with primary glioblastoma multiforme. Cancer 2013, 119:814-824.

81. Ji J, Shi J, Budhu A, et al: MicroRNA expression, survival, and response to interferon in liver cancer. N Eng J Med 2009, 361:1437-1447.

82. Gao W, Lu X, Liu L, Xu J, Feng D, Shu Y: MiRNA-21: a biomarker predictive of platinum-based adjuvant chemotherapy response in patients with non-small cell lung cancer. Cancer Biol Ther 2012, 13:330-340.

83. Weiss GJ, Bemis LT, Nakajima E, et al: EGFR regulation by microRNA in lung cancer: correlation with clinical response and survival to gefitinib and EGFR expression in cell lines. Ann Oncol 2008, 19:1053-1059.

84. Yang N, Kaur S, Volinia S, et al: MicroRNA microarray identifies let-7i as a novel biomarker and therapeutic target in human epithelial ovarian cancer. Cancer Res 2008, 68:10307-10314.

85. Hwang JH, Voortman J, Giovannetti E, et al: Identification of microRNA-21 as a biomarker for chemoresistance and clinical outcome following adjuvant therapy in resectable pancreatic cancer. PLoS One 2010, 5:e10630.

86. Giovannetti E, Funel N, Peters GJ, et al: MicroRNA-21 in pancreatic cancer: correlation with clinical outcome and pharmacologic aspects underlying its role in the modulation of gemcitabine activity. Cancer Res 2010, 70:4528-4538

87. Preis M, Gardner TB, Gordon SR, Pipas JM, et al: MicroRNA-10b expression correlates with response to neoadjuvant therapy and survival in pancreatic ductal adenocarcinoma. Clin Cancer Res 2011, 17:5812-5821.

88. Arroyo JD, Chevillet JR, Kroh EM, et al: Argonaute2 complexes carry a population of circulating microRNAs independent of vesicles in human plasma. Proc Natl Acad Sci USA 2011, 108:5003-5008.

89. Vickers KC, Palmisano BT, Shoucri BM, Shamburek RD, Remaley AT: MicroRNAs are transported in plasma and delivered to recipient cells by high-density lipoproteins. Nat Cell Biol 2011, 13:423-433.

90. Gallo A, Tandon M, Alevizos I, Illei GG: The majority of microRNAs detectable in serum and saliva is concentrated in exosomes. PLOS ONE 2012, 7:e30679.

91. Wang H, Tan G, Dong L, Cheng L, Li K, Wang Z, et al: Circulating miR-125b as a marker predicting chemoresistance in breast cancer. PLOS ONE 2012, 7:e34210.

92. Jung EJ, Santarpia L, Kim J, Esteva FJ, Moretti E, Buzdar AU, Di Leo A, Le XF, Bast RC Jr, Park ST, Pusztai L, Calin GA: Plasma microRNA 210 levels correlate with sensitivity to trastuzumab and tumor presence in breast cancer patients. Cancer 2012, 118:2603-2614.

93. Ng EK, Chong WW, Jin H, Lam EK, Shin VY, Yu J, et al: Differential expression of microRNAs in plasma of patients with colorectal cancer : a potential marker for colorectal cancer screening. Gut 2009, 58:1375-1381.

94. Kjersem JB, Ikdahl T, Lingjaerde OC, Guren T, Tveit KM, Kure EH: Plasma microRNAs predicting clinical outcome in metastatic colorectal cancer patients receiving first line oxaliplatin-based treatment. Mol Oncol 2013. doi: 10.1016/j.molonc.2013.09.001 
95. Wei J, Gao W, Zhu C, Liu YQ, Mei Z, Cheng T, et al: Identification of plasma microRNA-21 as a biomarker for early detection and chemosensitivity of non-small cell lung cancer. Chin J Cancer 2011, 30:407-414.

96. Ohyashiki K, Umezu T, Yoshizawa S, Ito Y, Ohyashiki M, Kawashima H, et al: Clinical impact of down-regulated plasma miR-92a levels in nonHodgkin's lymphoma. PLOS ONE 2011, 6:e16408.

97. Lucotti S, Rainaldi G, Evangelista M, Rizzo M: Fludarabine treatment favors the retention of miR-485-3p by prostate cancer cells: implications for survival. Mol Cancer 2013, 12:52.

98. Zhang HL, Yang LF, Zhu Y, Yao XD, Zhang SL, Dai B, et al: Serum miRNA-21: elevated levels in patients with metastatic hormone-refractory prostate cancer and potential predictive factor for the efficacy of docetaxel-based chemotherapy. Prostate 2011, 71:326-331.

99. Gamez-Pozo A, Anton-Aparicio LM, Bayona C, Borrega P, Gallegos Sancho Ml, Garcia-Dominguez R, et al: MicroRNA expression profiling of peripheral blood samples predicts resistance to first-line sunitinib in advanced renal cell carcinoma patients. Neoplasia 2012, 14:1144-1152.

100. Madhavan D, Zucknick M, Wallwiener $M$, et al: Circulating miRNAs as surrogate markers for circulating tumor cells and prognostic markers in metastatic breast cancer. Clin Cancer Res 2012, 18:5972-5982.

101. Hu Z, Chen X, Zhao Y, et al: Serum microRNA signatures identified in a genome-wide serum microRNA expression profiling predict survival of non-small-cell lung cancer. J Clin Oncol 2010, 28:1721-1726.

102. Xi Y, Nakajima G, Gavin E, et al: Systematic analysis of microRNA expression of RNA extracted from fresh frozen and formalin-fixed paraffin-embedded samples. RNA 2007, 13:1668-1674.

103. Hutvagner G, Zamore PD: RNAi: nature abhors a double-strand. Curr Opin Genet Dev 2002, 12:225-232.

104. Krutzfeldt J, Rajewsky N, Braich R, et al: Silencing of microRNAs in vivo with 'antagomirs'. Nature 2005, 438:685-689.

105. Elmen J, Lindow M, Silahtaroglu A, et al: Antagonism of microRNA-122 in mice by systematically administered LNA-antimiR leads to up-regulation of a large set of predicted target mRNAs in the liver. Nucleic Acids Res 2008, 36:1153-1162.

106. Dickins RA, Hamann MT, Zilfou JT, Simpson DR, Ibarra I, Hannon GJ: Probing tumor phenotypes using stable and regulated synthetic microRNA precursors. Nat Genet 2005, 37:1289-1295.

107. Tsuda N, Kawano K, Efferson CL, loannides CG: Synthetic microRNA and double-strand RNA targeting the 30-untranslated region of HER-2/neu mRNA inhibit HER-2 protein expression in ovarian cancer cells. Int J Oncol 2005, 27:1299-1306.

108. Liang Z, Wu H, Reddy S, Zhu A, Wang S, Blevins D: Blockade of invasion and metastasis of breast cancer cells via targeting CXCR4 with an artificial microRNA. Biochem Biophys Res Commun 2007, 363:542-546.

109. Li L, Xie X, Luo J, Liu M, Xi S, Guo J, Kong Y, Wu M, Gao J, Xie Z, et al: Targeted expression of mir-34a using the t-visa system suppresses breast cancer cell growth and invasion. Mol Ther 2012, 20:2326-2334.

110. Lee SJ, Kim SJ, Seo HH, Shin SP, Kim D, Park CS, Kim KT, Kim YH, Jeong JS, Kim IH: Over-expression of mir-145 enhances the effectiveness of hsvtk gene therapy for malignant glioma. Cancer Lett 2012, 320:72-80.

111. Wang X, Han L, Zhang A, Wang G, Jia Z, Yang Y, Yue X, Pu P, Shen C, Kang $C$ : Adenovirus-mediated shrnas for co-repression of mir-221 and mir-222 expression and function in glioblastoma cells. Oncol Rep 2011, 25:97-105.

112. Munoz JL, Bliss SA, Greco SJ, Ramkissoon SH, Ligon KL, Rameshwar P: Delivery of functional anti-miR-9 by mesenchymal stem cell-derived exosomes to glioblastoma multiforma cells conferred chemosensitivity. Mol Ther Nucleic Acids 2013, 2:e126.

113. Kota J, Chivukula RR, O"Donnell KA, Wentzel EA, Montagomery CL, Hwang HW, Chang TC, Vivekanandan P, Torbenson M, Clark KR, et al: Therapeutic microrna delivery suppresses tumorigenesis in a murine liver cancer model. Cell 2009, 137:1005-1017.

114. Trang P, Medina PP, Wiggins JF, Ruffino L, Kelnar K, Omotola M, Homer R, Brown D, Bader AG, Weidhaas JB, et al: Regression of murine lung tumors by the let-7 microrna. Oncogene 2010, 29:1580-1587.

115. Trang P, Wiggins JF, Daige CL, Cho C, Omotola M, Brown D, Weidhaas JB, Bader AG, Slack FJ: Systemic delivery of tumor suppressor microrna mimics using a neutral lipid emulsion inhibits lung tumors in mice. Mol Ther 2011, 19:1116-1122

116. Babar IA, Cheng CJ, Booth CJ, Liang X, Weidhaas JB, Saltzman WM, Slack FJ: Nanoparticle-based therapy in an in vivo microrna-155 (mir-155)-dependent mouse model of lymphoma. Proc Natl Acad Sci USA 2012, 109:E1695-E1704.
117. Murphy BL, Obad S, Bihannic L, Ayrault O, Zindy F, Kauppinen S, Roussel MF: Silencing of the miR-17 92 cluster family inhibits medulloblastoma progression. Cancer Res 2013, 73:7068-7078.

118. Sicard F, Gayral M, Lulka H, Buscail L, Cordelier P: Targeting miR-21 for the therapy of pancreatic cancer. Mol Ther 2013, 21:986-994.

119. Medina PP, Nolde M, Slack FJ: OncomiR addiction in an in vivo model of microRNA-21-induced pre-B-cell lymphoma. Nature 2010, 467:86-90.

120. Meng $F$, Henson $R$, Lang $M$, et al: Involvement of human micro-RNA in growth and response to chemotherapy in human cholangiocarcinoma cell lines. Gastroenterology 2006, 130:2113-2129.

121. Wong ST, Zhang XQ, Zhuang JT, Chan HL, Li CH, Leung GK: MicroRNA-21 inhibition enhances in vitro chemosensitivity of temozolomide-resistant glioblastoma cells. Anticancer Res 2012, 32:2835-2841.

122. Li Y, Li L, Guan Y, Liu X, Meng Q, Guo Q: MiR-92b regulates the cell growth, cisplatin chemosensitivity of A549 non small cell lung cancer cell line and target PTEN. Biochem Biophys Res Commun 2013, 440:604-610.

123. Weidhaas JB, Babar I, Nallur SM, et al: MicroRNAs as potential agents to alter resistance to cytotoxic anticancer therapy. Cancer Res 2007, 67:11111-11116.

124. Pan $X$, Wang ZX, Wang R: MicroRNA-21: a novel therapeutic target in human cancer. Cancer Biol Ther 2011, 10:1224-1232.

125. Iorio MV, Croce CM: Causes and consequences of microRNA dysregulation. Cancer J 2012, 18:215-222.

126. Rodrigues AC, Li X, Radecki $L$, et al: MicroRNA expression is differentially altered by xenobiotic drugs in different human cell lines. Biopharm Drug Dispos 2011, 32:355-367.

127. Shan G, Li Y, Zhang J, et al: A small molecule enhances RNA interference and promotes microRNA processing. Nature Biotech 2008, 26:933-940.

128. Melo S, Villanueva A, Moutinho C, et al: The small molecule enoxacin is a cancer-specific growth inhibitor that acts by enhancing TAR RNA-binding protein 2-mediated microRNA processing. Proc Natl Acad Sci USA 2011, 108:4394-4399.

129. Scott GK, Mattie MD, Berger CE, Benz SC, Benz CC: Rapid alteration of microRNA levels by histone deacetylase inhibition. Cancer Res 2006, 66:1277-1281.

130. Liu X, Wang S, Meng F, et al: SM2miR: a database of the experimentally validated small molecules's effects on microRNA expression. Bioinformatives 2013, 29:409-411.

131. Zhang S, Chen L, Jung EJ, Calin GA: Targeting microRNAs with small molecules: from dream to reality. Clin Pharmacol Ther 2010, 87:754-758.

132. Jiang W, Chen Z, Liao M, Li W, et al: Identification of links between small molecules and miRNAs in human cancers based on transcriptional responses. Sci Rep 2012, 2:282.

133. Grimm D, Streetz KL, Jopling CL, et al: Fatality in mice due to oversaturation of cellular microRNA/short hairpin RNA pathways. Nature 2006, 441:537-541.

doi:10.1186/1423-0127-20-99

Cite this article as: To: MicroRNA: a prognostic biomarker and a possible druggable target for circumventing multidrug resistance in cancer chemotherapy. Journal of Biomedical Science 2013 20:99.

\section{Submit your next manuscript to BioMed Central and take full advantage of:}

- Convenient online submission

- Thorough peer review

- No space constraints or color figure charges

- Immediate publication on acceptance

- Inclusion in PubMed, CAS, Scopus and Google Scholar

- Research which is freely available for redistribution 